\title{
Invited Review: Crossbreeding in Dairy Cattle From a German Perspective of the Past and Today
}

\author{
G. Freyer, ${ }^{* 1}$ S. König,† B. Fischer,ł U. Bergfeld,§ and B. G. Cassell\# \\ ${ }^{*}$ Research Institute for the Biology of Farm Animals (FBN), Unit Genetics and Biometry, 18196 Dummerstorf, Germany \\ †Georg August University, Göttingen, Institut für Tierzucht und Haustiergenetik, 37075 Göttingen, Germany \\ 扎andesanstalt für Landwirtschaft, Forsten und Gartenbau Sachsen-Anhalt, 39606 Iden, Germany \\ §Sächsische Landesanstalt für Landwirtschaft, 04886 Köllitsch, Germany \\ \#Department of Dairy Science, Virginia Polytechnic Institute and State University, Blacksburg 24061
}

\begin{abstract}
Several crossing experiments in dairy cattle are currently in progress. Most of them are based on HolsteinFriesian, superior in milk production, and Jersey, known for highly concentrated milk and early maturity. Crossbreeding can lead to combination of favorable characteristics from the breeds involved, based on breed additive genetic effects. Further, heterosis can be of additional economic benefit, but the magnitude of heterosis is not well established for many breed combinations, and traits and effects of heterosis are not heritable. These unknowns, and possible recombination losses in rotational crossbreeding systems, are the challenges to practical application of crossbreeding in dairy cattle. Crossbreeding, if widely implemented, impacts existing breeding schemes and should be pursued after careful economic evaluation. In the former East Germany, crossbreeding in dairy cattle led to a new synthetic breed, a milk-emphasized dual-purpose breed called Schwarzbuntes Milchrind der DDR (SMR). The SMR composite was based on a 3-breed cross, including native East German Black and White, Danish Jersey, and Canadian Holstein-Friesian. The SMR breed was used in commercial milk production in East Germany in the 1970s and 1980s. This paper describes the goals in creating and performance of SMR and summarizes related work during the SMR period. Current German crossing experiments and profitability for different amounts of heterosis will be introduced.
\end{abstract}

Key words: crossbreeding, heterosis, additive and nonadditive effect, economic evaluation

\section{INTRODUCTION}

Genetic diversity is the prerequisite for breeding success (Simianer et al., 2006), and rapid genetic change

Received April 21, 2008.

Accepted June 4, 2008.

${ }^{1}$ Corresponding author: freyer@fbn-dummerstorf.de by intense selection leads to gene loss (Schönmuth, 1985). A large number of studies (Fleischer et al., 2001) and practical experiences have shown that strict selection on high performance as done in the last decade for Holstein-Friesian is accompanied by unwanted side effects in metabolism, fertility, and health. Insufficient data-recording schemes for these secondary traits and low heritabilities complicate their inclusion in traditional breeding programs. Genetic antagonisms of first lactation performances and incidences of mastitis and ketosis, functional conformation traits, and longevity have been found in the vast majority of targeted studies, especially from North European countries where health-recording systems have been implemented for more than 20 yr (Heringstad et al., 2001).

Fitness in highly selected populations decreases with increasing distance from the original production level of a base population (Beckett et al., 1979), because a long-term directed intense selection on breeding goals disturbs genetic homeostasis (Kräußlich, 1999). Breeders of Bavarian Simmental stated that decreased longevity, greater stillbirth and calving losses, more frequent occurrence of inheritable disorders, and unfavorable correlations between protein yield and health traits are the main disadvantages of selection for greater production within pure dairy breeds (Rosenberger et al., 2004). In fact, deterioration of health and fertility have an important effect on dairy cow profitability in purebred dairy breeds and lead to decreasing milk production in further lactations (Gottensträter, 2007). Despite the advantages of selection within pure breeds, a single pure dairy breed is unlikely to fulfill all demands of milk producers on a long-term period. Besides several options for maintaining genetic diversity in German Holsteins, considerations and experiments on crossbreeding are underway, suggesting a tempting alternative (Swalve, 2007).

Characteristics of crossbred offspring are influenced by several effects, mainly by direct effects, parental effects, heterosis effects including dominance and epistasis, recombination loss, and effects for combi- 
nation suitability (Schüler et al., 2001). These effects depend on the breeds involved and the trait of interest and have been described in theory by different authors (Hill, 1971; Schüler et al., 2001). Genotype $\times$ environment interactions may also play a role, but they are currently not under focus in studies of crossbreeding in dairy cattle. Heterosis effects are expected to be large, when the trait-related differences of parental breeds are large. Jersey shows the largest genetic distance from Holstein-Friesian (HF) among dairy cattle breeds (Basedow, 1998). A detailed view of crossbreeding schemes for dairy cattle and of heterosis estimates from the literature is given by Sorensen et al. (2008). According to Hill (1971), a crossing system should lead to a constant genetic composition affecting trait-specific performances. Generally, it should be clear that heterosis effects are not heritable additions accompanying the combined additive effects as a bonus of a cross and decreasing in advanced generations of crosses. As one crossbreeding system suggested for dairy cattle, rotation crosses result in a cyclical gene composition from generation to generation (Schüler et al., 2001). The decrease of heterosis effects in rotational crosses depends on the number of breeds involved (Hill, 1971). Two breed rotations maintain $67 \%$ of $\mathrm{F} 1$ heterosis at equilibrium, and 3 breed rotational crosses maintain $86 \%$ of $\mathrm{F} 1$ heterosis.

Crossbreeding appears to have application in commercial dairy production, although heterosis for yields may be less than in economically important traits of poultry or pigs (Kräußlich, 1999). In contrast to other farm animals, Swalve (2004) suggested that crossbreeding programs are useful for dairy cattle only in those cases in which fertility and longevity are especially important. The contradiction between steadily increasing milk yield (MY) and decreased length of productive life or impaired fertility is a growing problem in German Holsteins. As one specific example, MY of German Holstein-registered cows increased steadily from 7,014 $\mathrm{kg}$ per $305 \mathrm{~d}$ in 1996 up to $8,672 \mathrm{~kg}$ in 2006, whereas longevity decreased from 4.9 to $4.6 \mathrm{yr}$ during the same period (ADR, 2007). Simultaneously, fat and protein content decreased by 0.23 and $0.03 \%$, respectively. Increased calving intervals affect economy negatively. Moreover, inbreeding and genetic drift within a breed may create further problems.

To cope with these problems, several research groups in cooperation with dairy cattle farms in Germany started limited crossbreeding experiments. Crossing experiments, especially with Holstein and Jersey, are not a new idea. A practical experiment crossing German Black and White (SR) dairy cows and Danish Jersey sires started in the 1940s in Dummerstorf in northeast Germany (Schmidt, 1948). Crosses of SR cows and Jer- sey sires in both parts of Germany increased fat content (FC) and fat yield within homogeneous F1 production herds (Schlie, 1949). Conclusions concerning body development and MY from a large crossing experiment in West Germany included heterosis effects up to 8\% (Witt et al., 1973a,b). In the 1960s, an additional cross using Canadian Holsteins produced a composite dairy breed, called Schwarzbuntes Milchrind der DDR (SMR). The motivation was very different from the considerations of today. The purpose was to develop a milk-emphasized, dual-purpose breed starting from the existing dairy population within East Germany (Schönmoth, 1963).

The primary focus of this paper is to review the 3-breed cross, including the main scientific and practical results of the breeding process. Furthermore, we report motivations and preliminary results of current crossbreeding experiments in Germany and economical aspects related to specific crossbreeding designs.

\section{BLACK PIED DAIRY CATTLE OF EAST GERMANY}

\section{Background of Creating a New Breed by Crossbreeding}

During the late 1950s and early 1960s in East Germany, a simple grading up of SR with HF sires, as done at that time in West Germany, was not considered the optimal breeding strategy. An increased demand for butter fat for human food supply combined with strict limitations in food supply for animal production was not achievable by using HF sires. The most economical dual-purpose cattle was described as small-framed with high fat- and protein-concentrated milk and sufficient ability for meat production. Improvement of functional traits, such as early breed maturity and a long productive life, was also of special interest. A thorough and detailed analysis of possible dairy breeds for the breeding objective was outlined by Schönmuth (1963). The plan was to rely on additive breed effects to produce a new synthetic breed that met the breeding goals. The continued crosses with Jersey and SR (Stahl et al., 1959; Lenschow, 1961; Lenschow and Tilsch, 1963) could be viewed as a preliminary step to creating SMR.

\section{Time-Related Description of Involved Breeds}

Breed averages for HF, Jersey, and SR breeds for production traits, first lactation culling, productive life, and stillbirths in calves are shown in Table 1. The SR breed, which was restricted primarily to East Germany at this time, was of smaller frame and lower milk production (MY) compared with the modern HF. 
Table 1. Average performances in production and functional traits for breeds involved in development of the Schwarzbuntes Milchrind der DDR breed (Schönmuth et al., 1980)

\begin{tabular}{|c|c|c|c|c|c|c|c|c|c|c|}
\hline \multirow[b]{2}{*}{ Breed $^{1}$} & \multirow[b]{2}{*}{ Code } & \multirow[b]{2}{*}{ Number } & \multicolumn{4}{|c|}{ First lactation performances completed } & \multicolumn{4}{|c|}{ Life performances } \\
\hline & & & $\begin{array}{l}\text { Milk } \\
\text { yield } \\
(\mathrm{kg})\end{array}$ & $\begin{array}{c}\text { Fat } \\
\text { yield } \\
(\mathrm{kg})\end{array}$ & $\begin{array}{c}\text { Fat } \\
\text { content } \\
(\%)\end{array}$ & $\begin{array}{l}\text { Protein } \\
\text { yield } \\
\text { (kg) }\end{array}$ & $\begin{array}{l}\text { Culling } \\
\text { in first } \\
\text { lactation } \\
(\%)\end{array}$ & $\begin{array}{l}\text { Days of } \\
\text { productive } \\
\text { life }^{2}\end{array}$ & $\begin{array}{c}\text { Life } \\
\text { performance } \\
\text { milk yield }^{2} \\
(\mathrm{~kg})\end{array}$ & $\begin{array}{c}\text { Calves } \\
\text { death } \\
\text { born }(\%)\end{array}$ \\
\hline $\mathrm{HF}$ & 03 & 100 & 6,555 & 236 & 3.60 & 209 & 3.01 & 1,403 & 21,959 & 8.87 \\
\hline Jersey & 08 & 183 & 3,241 & 204 & 6.30 & 138 & 15.90 & 1,444 & 19,142 & 2.97 \\
\hline
\end{tabular}

${ }^{1} \mathrm{HF}=$ Holstein-Friesian cattle; Jersey = Danish Jersey cattle; SR = native Black and White cattle population in East Germany.

${ }^{2}$ Breed-specific observations in life performance traits are biased by trends over time for specific breeds, herds, and environmental effects.

However, the breed was considered superior to HF for slaughter traits, giving it an advantage in production of meat. The breed was predominately blacker than $\mathrm{HF}$, and fertility and longevity were reasonably good. The SR breed maintained adequate performance under poorer environmental conditions, including feed quality and quantity, than HF. The MY in SR was constant between 1955 and 1962 and averaged less than 3,000 $\mathrm{kg}$ in 1963. In addition, there was no increase in fat yield and fat content. Mean performances of herd book cows reached about $120 \mathrm{~kg}$ and $3.60 \%$ fat. As a further practical problem, milking ability and quality of udder traits were insufficient for machine milking.

Danish Jersey (J) was better adaptable to machine milking and had greater contents of milk fat and protein than SR. Hence, 6 Jersey sires were chosen for the first crosses on SR females because of their high breeding values (BV) for fat and protein percentage. Danish Jerseys were also known for early sexual maturity, expressed in young ages at first calving, and expressed high nonreturn rates. This breed was known for its small frame (about $400 \mathrm{~kg}$ of adult body weight), refined bone structure, and brown coat color. The superiority in MY per body weight unit was emphasized by Horn (1973).
Sires of the larger framed HF, as it was bred in the United States and Canada, were used to increase milk production, body and frame size, and udder traits. The HF breed is well known for high MY, lower percentages in fat and protein, and excellent udder shape and quality that is suitable for machine milking. A drawback was a later age at first calving. A comprehensive historical review of sperm imports and use of sires Brown, Glen, Ponto, Walter, and Witt and development of breeding values was reported by Pötke and Panicke (1993).

\section{The SMR Breeding Program}

Schönmuth (1963) suggested the crossbreeding program to create the composite breed (i.e., a milk-emphasized, dual-purpose cattle with high milk fat and protein content) and udder structure acceptable for machine milking based on a 3-breed cross (Figure 1). A longterm breeding goal was formulated as follows: annual milk production of a cow was targeted to reach 5,000 to $6,000 \mathrm{~kg}$ with $4 \%$ fat, reaching at least $200 \mathrm{~kg}$ of fat and $165 \mathrm{~kg}$ of protein, and sufficient muscling for $600 \mathrm{~kg}$ of body weight, and 128 to $132 \mathrm{~cm}$ in height at withers. In 1975, pure breeding of SMR began (Zelfel, 1974). Sires for reproduction originated from 12 bloodlines initially

Table 2. Average performances of elite bull dams and all dairy cows during the period of establishing the Schwarzbuntes Milchrind der DDR breed (Baum, 1986; Geissler et al., 1989; Zelfel, 1990b)

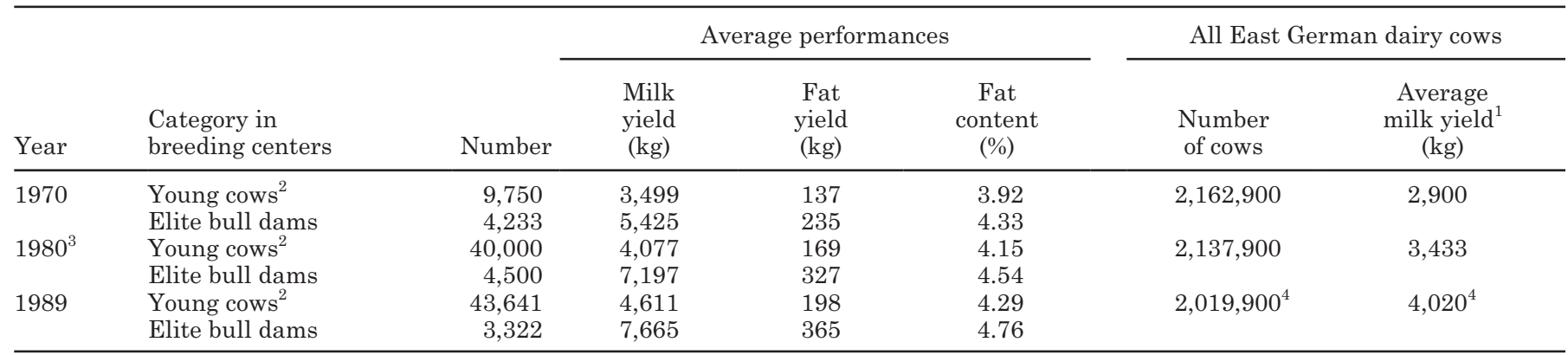

${ }^{1}$ Milk yield corrected to $4 \%$ milk fat.

${ }^{2}$ In first lactation.

${ }^{3}$ Number of animals roughly for 1980 .

${ }^{4}$ In 1988. 
and decreased in later years to 6 and 3 blood lines. The progeny testing program and genetic evaluation of SMR sires in the initial phase considered production traits, growth performances, and udder shape. Semen of roughly 500 young sires per year was distributed equally across large-scale testing farms, which utilized random mating except for strict avoidance of inbreeding. This breeding strategy produced about 50 effective daughters per sire for genetic evaluation, which was carried out by the East German computing center in Paretz, Brandenburg. Sire selection on coat color and pattern started about 1985, to avoid inheritance of carriers of too much black and unwanted patterns. Also, genetic evaluation was extended toward a combined evaluation of type and body shape during the 1980s. However, breeding goals and weighting factors of traits in a combined breeding goal were adjusted to natural conditions of production such as rough forage quality, grain availability, and grain price (Schwark, 1986a).

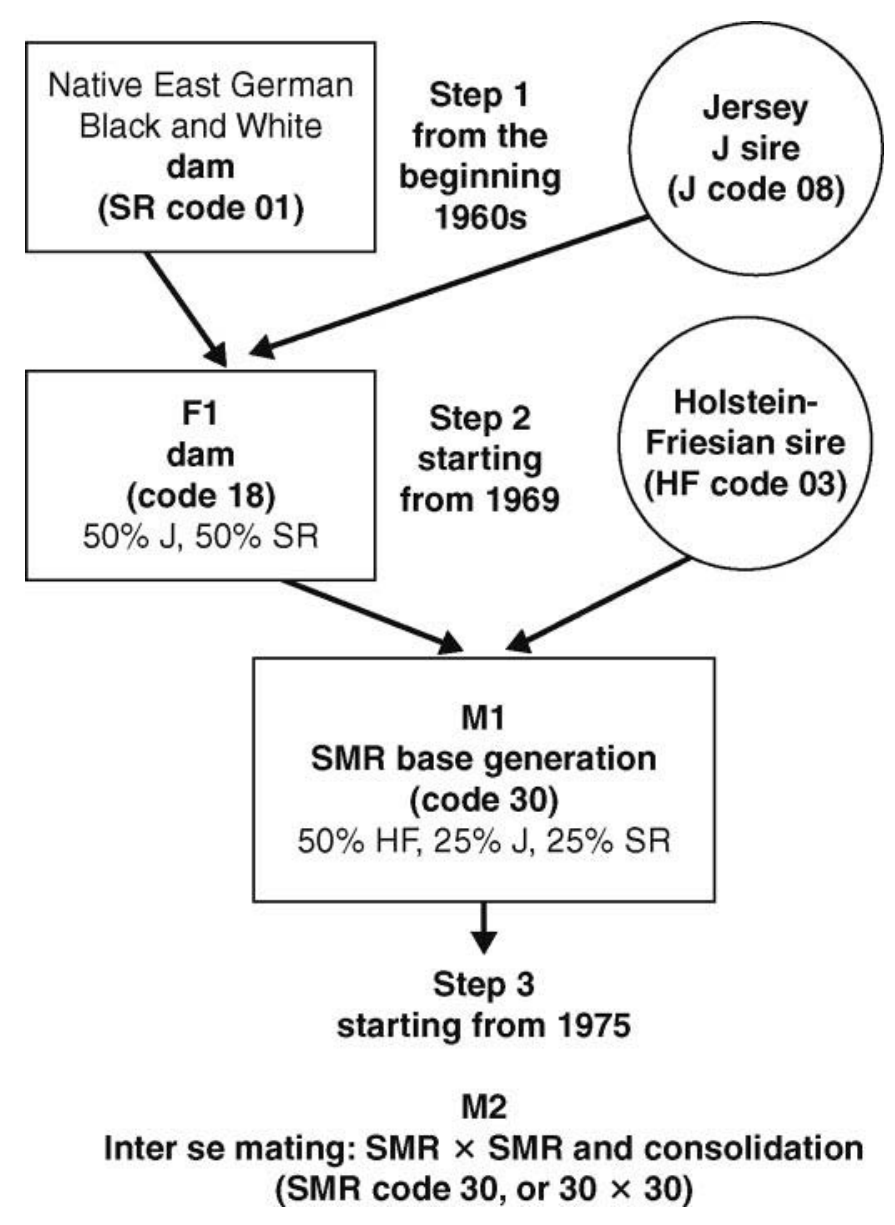

Figure 1. Scheme of crossing breeds Danish Jersey, native East German Black and White, and Holstein-Friesian during the process of creating the Schwarzbuntes Milchrind der DDR (SMR) in East Germany (according to the concept by Schönmuth, 1963).
Selection criteria for SMR elite bull dams from 1986 to 1990 were as follows: 7,000 to $7,500 \mathrm{~kg}$ of milk per $305 \mathrm{~d}$ of lactation, 4.5 to $5 \%$ fat and 3.5 to $3.7 \%$ protein, body weight at least $600 \mathrm{~kg}$, height between 135 and $140 \mathrm{~cm}$, and broadness of pelvis of $49 \mathrm{~cm}$ (Baum, 1986; Kramer and Wiegand, 1986). Criteria relative to reproduction included a maximum age at first insemination of $640 \mathrm{~d}$ and a calving interval between 350 and $370 \mathrm{~d}$. Physical criteria measured on breeding sires included height of 126 to $132 \mathrm{~cm}$, pelvis width of $44 \mathrm{~cm}$, and a weight between 430 and $460 \mathrm{~kg}$ at the age of $1 \mathrm{yr}$.

\section{Results of SMR Breeding-A Source for Research and Practice}

SMR Applied to the East German Dairy Breeding System. Performance of SMR relative to SR was considered to be $125 \%$ for MY, $115 \%$ for milk protein yield, equal in growth and fattening performance, and 95\% of slaughter performance (Panicke et al., 1982). Elite bull dams showed a substantial increase in average production during the process of creating and establishing SMR (Table 2). Many studies involved the relationship of body development in a heifer to its ultimate milk production as a cow. The association of greater MY with greater body weight postpartum in first lactation was clearly more pronounced in SMR than in SR (Panicke et al., 1983). Several studies confirmed the positive effects of length, height, broadness, and depth of body on milk production. Decreasing MY would follow a decrease in only one of these traits [e.g., decreasing broadness (Schwark, 1986a)]. The performance of SMR cattle to other breeds was carefully studied (Neumann et al., 1980; Matthes et al., 1985; Beckert et al., 1986; Neumann and Zupp, 1986; Seeland, 1986). Correlation coefficients between BV of carcass traits in fattening bulls and female growth performances ranged from 0.15 to 0.36 . Heritability coefficients varied among 0.23 to 0.40 for net daily gain in grams and carcass weight in kilograms, respectively. The SMR breed was considered to be a useful combination of high MY and reasonable meat production of good quality (Borrmann et al., 1986; Roffeis and Zelfel, 1989). Breeding of dual-purpose cattle considers some compromises in individual traits (Kramer and Wiegand, 1986). Results of SMR in beef developing traits compared with other dual-purpose crosses in cattle were summarized by Schwark (1986a), underlining the importance of genetic correlation when defining combined breeding goals. Correlation coefficients of BV for growth performance and milk production traits ranged from 0.122 to 0.235 (Zelfel and Sieber, 1986), whereas earlier reports by Leuthold and Leucht (1980) showed small or slightly negative correlations from -0.12 to 
0.09. Rybka (1979) reported moderate positive correlations of 0.3 and 0.4 between own performance for dry matter intake in bulls and growth performance of their daughters. Wolf (1986) and Beilig (1987) discussed feed intake and body capacity in a total merit index for dairy bulls. However, Schönmuth and Seeland (1986) suggested that further emphasis on growth and fattening traits could reduce the competitive ability of SMR on the international market, in light of different economic conditions in East and West Europe during the 1980s (Schwark, 1986b).

Kräußlich (2002) stated that the success of the SMR as a new breed was a unique situation, because the lack of competition in a socialist country allowed the development process to survive difficulties that might doom breed development to failure under other circumstances. However, SMR was also positively evaluated by breeders in other countries (e.g., Bozo et al., 1983). In fact, SMR was a useful breed for commercial milk production under suboptimal management and feeding conditions prevalent in East Germany at that time.

SMR as a Valuable Basis for Breeding Research. Seeland et al. (1984) compared heritability coefficients for production traits from different genetic groups involved in creation of SMR. The greatest heritabilities for single production traits were found in HF (in particular for MY $h^{2}=0.35$, for fat yield $h^{2}=0.33$, and for protein percentage $h^{2}=0.31$, as shown in Figure 2), whereas the lowest heritabilities were for the crossing group $J \times$ SR. Genetic correlations were highly positive among yield traits. In several studies, the lowest correlations were found in the crossing group $\mathrm{J} \times \mathrm{SR}$ (in F1 and F2), whereas results for SR and SMR were more similar (Figure 2). The varying correlations show that the breeding goal became much more complex in SMR, and as several authors assumed, a simultaneous increase of MY and protein content was not possible. This trait antagonism has a genetic basis and responds to intense selection (Schönmuth and Seeland, 1986). Differences in frequencies of milk protein alleles in different cattle breeds could be one reason for changing correlations between content and yield traits (Freyer et al., 1999). For example, for a closer protein:fat ratio, HF genes were favorable, whereas Jersey genes contribute to increasing fat content. However, there is also a substantial lack of information about the correlations among content traits and various other trait complexes. Thorough analysis of Jersey and HF crossbreds including genome analysis are currently underway and will contribute to our understanding of these relationships.

A long-term scientific experiment on milk protein was carefully designed and carried out in Clausberg (Thuringia) involving the different genetic groups of cows during the SMR breeding phase. Breitenstein et al. (1990) summarized the main results.

Several questions on how to improve SMR following its establishment had to be answered simultaneously with development of the breed. The breeding organization and the continuously developing breeding goal for SMR through classical breeding approaches needed accompanying research activities; moreover, even the trait-specific additive and nonadditive effects were unknown at the time of establishment.

\section{Nonadditive Effects for Improving Specific and General Performances}

In a highly variable environment, only heterozygous individuals are able to produce the vital, new genetic combinations within their offspring for survival of the population (Wessely, 1988, based on Kacser and Burns, 1981). We generally do not expect such extreme changes in modern dairy cattle breeding systems. However, the problem is to improve functional traits showing low heritabilities. They are of increasing economic importance in modern dairy cattle due to their effect on production costs. Whereas additive effects can be readily exploited to improve highly heritable production traits, the use of possible nonadditive effects may be more critical to maintain or improve fertility, health, adaptability, and longevity. By standard definition, in a cross of 2 pure breeds, heterosis is the deviation of performances of an offspring from the parental mean. According to the dominance hypothesis, nonadditive genetic effects are those caused by heterozygosity at a gene locus (dominance and overdominance), combinations of dominant genes at different loci, and various types of nonallelic gene-gene interactions, such as additive $x$ additive, dominant $x$ dominant, and additive $x$ dominant gene interactions (epistasis).

Gene $\times$ gene interaction exists if 1 gene suppresses or modifies expression of a different gene. Two genes interact if their joint effect deviates from the sum of single gene effects. Understanding the complex design of epistasis is important to understand the genetic architecture of a quantitative trait (Carlborg and Haley, 2004). As an example, gene $\times$ gene interaction effects explained about $30 \%$ of the phenotypic variance within an F2 mouse population (Schwerin, 2001). Additive $\times$ additive epistatic interactions of individual loci within the entire genetic background were identified to be a major component of heterozygosity (Melchinger et al., 2007). The different mechanisms of gene expression and a wide variety of gene interactions likely play an important role in functional traits such as fertility, disease resistance, and longevity (Dempfle, 2004). Reduction in genetic diversity, as produced by selection 
and pure breeding, reduces the ability of an organism to effectively respond to multipurpose demands.

In later generations following a cross of traitdivergent breeds, the positive effects of a new genetic construction can be reduced by recombination loss. By theory, recombination loss is expected to occur if a favorable combination of 2 or more linked alleles affecting a trait (or trait complex) is broken apart by crossover during meiosis. Further, in inter se mating of crossbred animals, a breakdown of favorable heterozygous gene combinations, can reduce the positive effects of heterosis on a production trait. Epistatic effects and recombination loss are dependent on the design of a crossbreeding program and thus not heritable or permanent from one generation to the next. New studies show that the genetic basis of the biological phenomenon of heterosis is still of great interest and has not yet been completely elucidated (Melchinger et al., 2007).

\section{Heterosis Field Experiment}

Experimental Design. Panicke et al. (1975) reviewed approaches of estimating additive breed effects and non-additive effects in a cross, to construct a design to estimate those effects in SMR. This effort led to the implementation of the Heterosisfeldversuch (HFV) experiment (Panicke, 1986; Panicke et al., 1990). An extensive crossing design with additional crossing groups as shown in Table 3 was implemented in a large field experiment including several large-scale dairy farms, located in Mecklenburg-Lower Pomeranian and Saxony-Anhalt. In addition to the regular crossing groups (Figure 1), an inter se cross (F2) from Jersey $\times$ SR mating (code $18 \times 18$ ), an F1' (code 13), and a backcross (R1', code 12$)$ of $\mathrm{SR} \times \mathrm{HF}$ were needed. Three unrelated sires in each breed (Jersey and HF) were used. Herds were divided into 3 levels based on average fat yield in $305 \mathrm{~d}$ in first lactation: (i) lower level of less than $150 \mathrm{~kg}$, (ii) medium level averaging about $160 \mathrm{~kg}$ of fat, and (iii) a high level group of $180 \mathrm{~kg}$ of fat and more. The estimation of additive and heterosis effects was based on the medium level, to avoid the disturbing effects of feeding stress (in the low level), and of preferential treatment of individual cows practiced within small herds in the high group. Differences in mean performances of all involved crossing groups were in agreement with the expectations (Table 3).

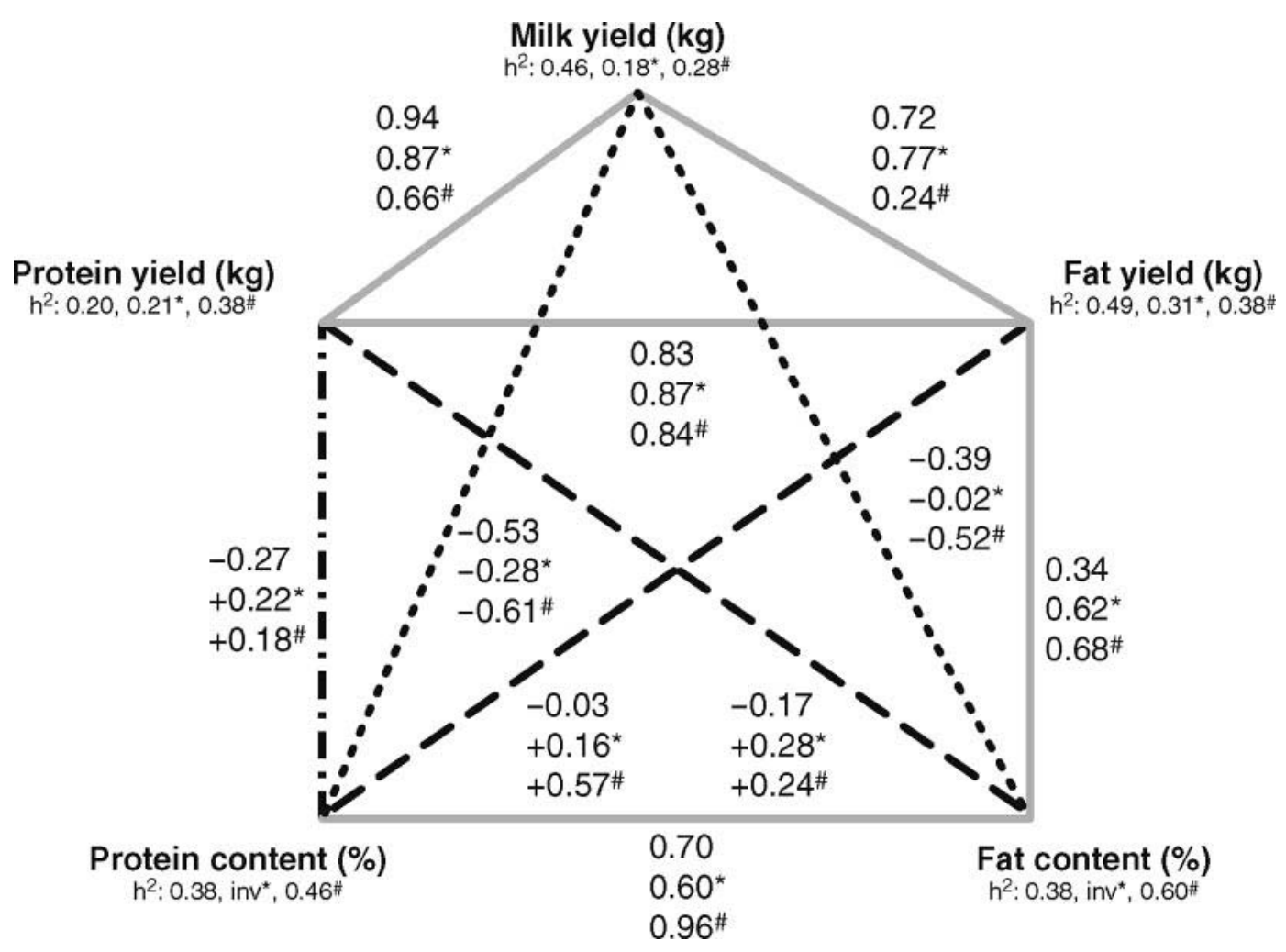

Figure 2. Genetic correlations of milk production traits in SMR (Fiedler et al., 1990) in comparison to pure SR (*) and crossing group SR by Jersey (\#), and heritability coefficients (Droese et al., 1985) based on a large material from the contemporary East German crossing population. SMR = Schwarzbuntes Milchrind der DDR breed; SR = native Black and White cattle population in East Germany. 
Table 3. Means and standard deviations production traits in first lactation (305 milking days) and for productive life for breeds and crossing groups involved in the heterosis field experiment (Heterosisfeldversuch), selected from herds with a medium production level of about $140 \mathrm{~kg}$ of fat (Panicke and Freyer, 1992; Freyer and Panicke, 1993)

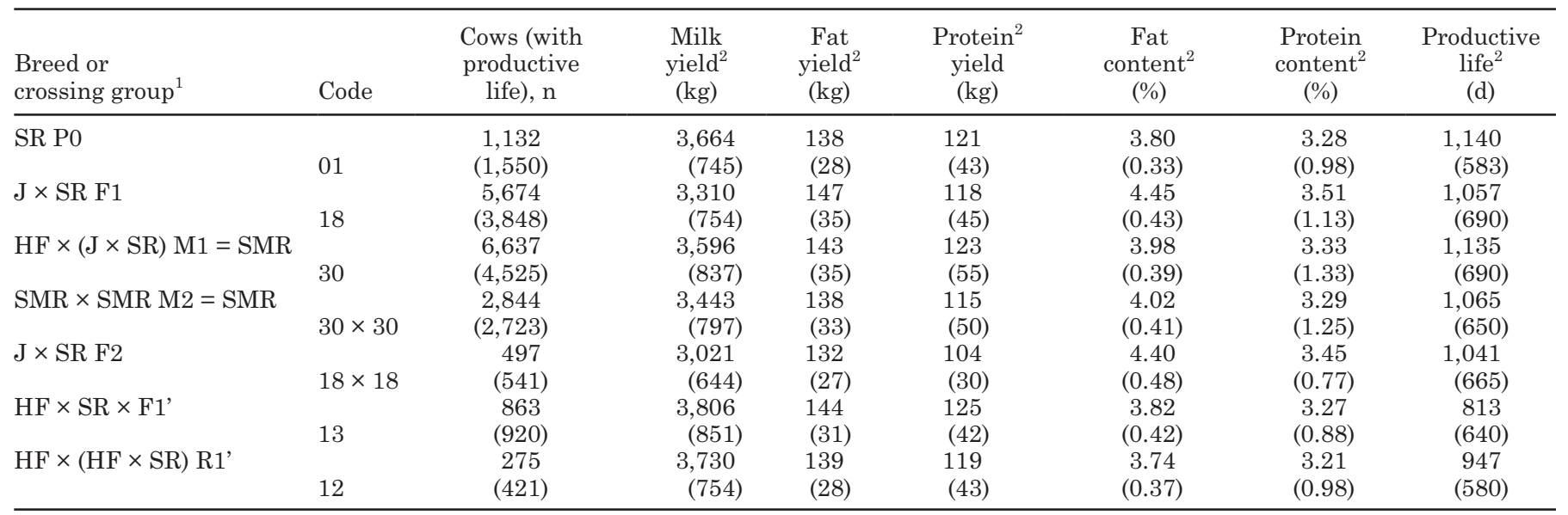

${ }^{1} \mathrm{SR}=$ native Black and White cattle population in East Germany; J = Danish Jersey cattle; HF = Holstein-Friesian cattle; SMR = Schwarzbuntes Milchrind der DDR breed.

${ }^{2}$ Mean (SD).

Actual yields were adjusted for effects of calving age, herd, year, and season of calving to obtain individual adjusted performances for estimating additive and nonadditive effects. Methods and results of estimation are reported in detail by Panicke and Freyer (1992). The main model was a simple dominance model. A maternal effects model was applied to traits related to body development, where such effects were expected to play an important role (Dietl, 1987). Several crossing groups were missing or did not provide enough data to enable estimation of epistatic effects or recombination losses. For example, the F2' generation from $\mathrm{HF} \times$ $\mathrm{SR}$ and backcrosses of $\mathrm{J} \times(\mathrm{J} \times \mathrm{SR})$ and $\mathrm{SR}(\mathrm{HF} \times \mathrm{SR})$ were not available. Estimates of recombination loss or epistasis were insignificant.

Results in Milk Traits. Estimated additive breed effects of $\mathrm{HF}$ on MY confirmed the superiority of $\mathrm{HF}$ (Table 4). Note that the additive and heterosis effects in Tables 4 and 5 are given as relative values in trait units (kg for yield traits and \% for content traits). To distinguish estimated heterosis effects from denoting crossing groups, we use abbreviations J_SR, HF_SR, and J_HF for denoting the nonadditive effects associated to the specific breed origins.

The greatest heterosis effect for MY of $4.5 \%$ was obtained by the combination J_HF, followed by HF_SR. The combination HF_SR was inferior in fat yield, and here, the greatest heterosis effect was obtained from J_SR of about $4 \%$. The lowest heterosis effect in content traits was from the combination HF_SR. An extended model including epistatic effects (Wessely et al., 1985, $1986,1987)$ revealed similar results. However, due to a greater number of parameters to be estimated by the epistatic model and lack of data in specific backcrosses, errors of estimates for heterosis and epistatic effects were extremely large (Table 5).

Table 4. Estimated additive and heterotic effects $( \pm \mathrm{SE})$ for breeds involved in the heterosis field experiment for production traits (Panicke and Freyer, 1992) and productive life (Freyer and Panicke, 1993) based on a simple dominance model

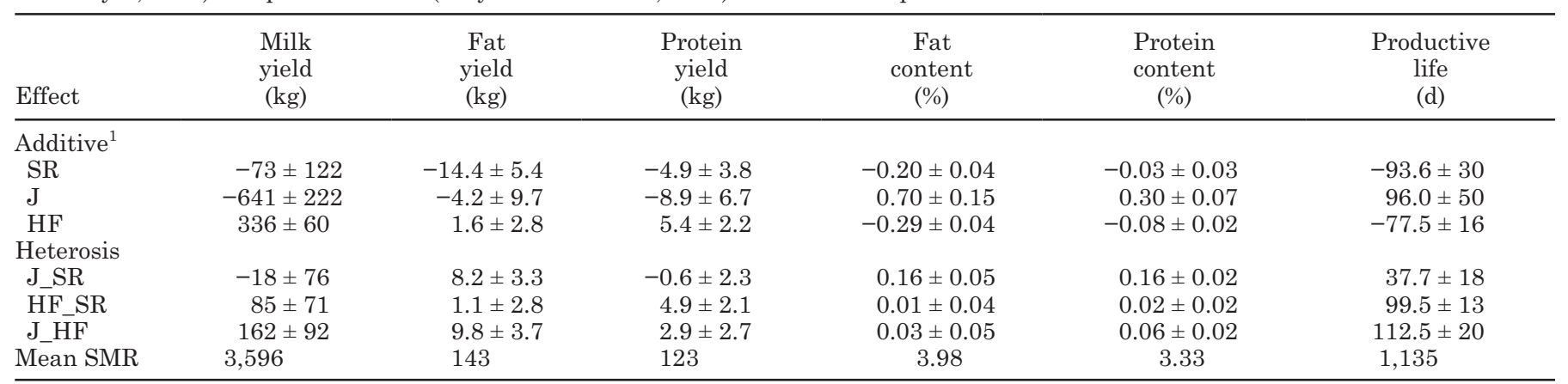

${ }^{1} \mathrm{SR}=$ native Black and White cattle population in East Germany; $\mathrm{J}=$ Danish Jersey cattle; HF = Holstein-Friesian cattle (based on sires from Canadian Holstein population); heterosis components refer to the breed origins. SMR = Schwarzbuntes Milchrind der DDR breed. 
Table 5. Estimates of additive, dominance, and epistatic effects and recombination loss on specified milk traits from studies of U. Bergfeld (Leipzig University, Germany; unpublished data, 1992), Großhans et al. (1993), and Wessely et al. (1985)

\begin{tabular}{|c|c|c|c|c|c|c|}
\hline Category of effect ${ }^{1}$ & \multicolumn{2}{|c|}{ Milk yield (kg) } & \multicolumn{2}{|c|}{ Fat yield (kg) } & \multicolumn{2}{|c|}{ Fat content (\%) } \\
\hline \multicolumn{7}{|l|}{ Additive breed } \\
\hline SR & 0 & $\mathrm{NA}^{3}$ & 0 & NA & 0 & NA \\
\hline $\mathrm{J}$ & 18 & $-672^{*}$ & $15.2^{* *}$ & 8.3 & $0.46^{* *}$ & $1.23^{* * *}$ \\
\hline J_SR & $110^{* *}$ & 8 & 1.4 & -2.7 & $-0.10 * *$ & -0.18 \\
\hline HF_SR & $24^{* *}$ & -130 & 0.4 & -6.5 & $0.04^{* *}$ & -0.08 \\
\hline J_HF & $6^{* *}$ & 182 & 11.7 & 16.8 & 0.23 & 0.09 \\
\hline \multicolumn{7}{|l|}{ Recombination loss } \\
\hline J_SR & $-250 * *$ & -200 & $-11.6^{* *}$ & -30.1 & -0.02 & $-0.66^{* * *}$ \\
\hline HF_SR & -38 & -318 & -1.3 & -14.7 & 0 & -0.11 \\
\hline J_HF & $206^{*}$ & -107 & 6.3 & -4.8 & -0.11 & -0.15 \\
\hline $\mathrm{HF}$ & $73 \pm 36$ & $799 * *$ & $-0.7 \pm 1.36$ & 18.1 & $-0.09 \pm 0.016$ & -0.30 \\
\hline \multicolumn{7}{|l|}{ Dominance } \\
\hline J_SR & $-619 \pm 148$ & 212 & $16.5 \pm 6.06$ & 27.7 & $-0.09 \pm 0.117$ & $0.49 * *$ \\
\hline HF_SR & $490 \pm 261$ & 124 & $7.9 \pm 19.03$ & 6.8 & $-0.41 \pm 0.084$ & 0.07 \\
\hline J_t̄F & $368 \pm 216$ & 372 & $19.9 \pm 8.67$ & 23.6 & $-0.28 \pm 0.126$ & 0.19 \\
\hline \multicolumn{7}{|l|}{ Epistatic } \\
\hline J_SR & $-388 \pm 64$ & -411 & $-4.6 \pm 3.82$ & -60.4 & $0.38 \pm 0.050$ & $-1.31^{* * *}$ \\
\hline HF_SR & $-34 \pm 247$ & -499 & $-5.2 \pm 9.46$ & -26.6 & $0.23 \pm 0.127$ & -0.30 \\
\hline J_HF & $-226 \pm 287$ & -363 & $-17.1 \pm 11.52$ & -12.8 & $-0.03 \pm 0.152$ & -0.20 \\
\hline
\end{tabular}

${ }^{1} \mathrm{SR}=$ native Black and White cattle population in East Germany; $\mathrm{J}=$ Danish Jersey cattle; HF = Holstein-Friesian cattle; heterosis components refer to the breed origins.

${ }^{2}$ Results including effects of recombination loss in U. Bergfeld (Leipzig University, Germany; unpublished data, 1992) and Großhans et al. (1993) were obtained from the Dickerson model (Dickerson, 1969); results including epistatic effects in Großhans et al. (1993) based on the Jacubec model (Jacubec et al., 1987).

${ }^{3} \mathrm{NA}=$ not applicable.

${ }^{4}$ Wessley et al. (1985).

${ }^{*} P<0.10 ;{ }^{* *} P<0.05 ; * * * P<0.01$.

Two further studies in addition to HFV were carried out on additive and nonadditive effects using the entire East German dairy population. Additive effects reported by Großhans et al. (1993) were larger than by the HFV study. In the same study, the greatest heterosis effects in MY and fat yield were estimated for combination J_HF, consistent with the HFV project. Heterosis effect of J_HF on FC was $0.09 \%$, compared with $0.03 \%$ in HFV (Panicke and Freyer, 1992). A second study of nonadditive effects on milk traits was carried out by Bergfeld (1991). A large recombination loss of $-250 \mathrm{~kg}$ of milk was found for J_SR, whereas the corresponding dominance effect was $110 \mathrm{~kg}$ (Table 5). Large differences of estimated recombination losses were found in both studies (Table 5). Großhans et al. (1993) and U. Bergfeld (Leipzig University, Germany; unpublished data, 1992) used data from the basic SMR population, regardless of production levels of the herds involved.
This could likely be the reason for overestimating these effects. Evaluation of epistatic effects led to a similar conclusion (Table 5).

Results for Productive Life and Maternal Fertility. The data for estimating effects of productive life and maternal fertility was based on a medium-level group for milk traits, apart from deviating sample sizes (Tables 3 and 6). Here, we refer to the number of total productive milking days of a cow (excluding dry days). In Table 4, only the Jersey breed showed a favorable breed additive estimate of $96 \mathrm{~d}$ in productive life. However, heterosis effects were always positive, and greatest in J_HF (112.5 d), followed by HF_SR (99.5 d). The negative additive effect of SR was most likely biased by the relatively low means of crossing groups based on SR and HF. On the other hand, a remarkable heterosis effect J_SR of $37.7 \mathrm{~d}$ was found (Table 4). Heritability for productive life and number of lactations was low 
(i.e., 0.019 and 0.125, respectively; Lehmann, 1987). Genetic correlation of MY in first lactation and productive life and number of lactations was 0.17 and 0.30 , respectively.

Some crossing groups had incomplete data to evaluate fertility traits. Therefore, additive and nonadditive effects could not be estimated. Mean trait values of the crossing groups were similar within district 1 or district 2 (Table 6). Districts 1 and 2 are groups of several farms located in 2 different areas of East Germany. Relatively large differences between both districts underline the known dependence of fertility traits on management conditions (Schwalbe, 1982, 1986). The F2 generation (Jersey $\times \mathrm{SR}$, inter se) showed the lowest number of days open in first lactation, followed by the $\mathrm{J} \times \mathrm{SR}(\mathrm{F} 1)$, and the inter se mating SMR $\times \mathrm{SMR}(\mathrm{M} 2)$. There was a clear suggestion of positive fertility characteristics for the Jersey breed and strong suggestion to advantageous heterosis.

Results in Growth Performances and Beef Development Ability. Maternal effects do play a role in several traits describing body weight and development (Panicke et al., 1985; Matthes et al., 1988). Heterosis effects of about 7\% were found for body weight at 12 mo for HF_SR. Positive heterosis effects on adult body weight and slaughter weight were also found for J_HF. Maternal effects of Jersey in rate of gain became distinctly negative for older ages. Additive effects for slaughter weight were about $24 \mathrm{~kg}$ greater in SR than in $\mathrm{HF}$.

The HFV study showed that heterosis effects were favorable for stabilizing milk and growth performances and functional traits in SMR. Based on the experimental design and approached methods of analysis, it can be concluded that there was no overestimation of additive and heterosis effects based on the simple dominance model. Models incorporating epistasis or recombination loss could provide more detailed information for the long-term selection response, but the lack of sufficient backcrosses limited reliable results. Modeling epistasis is far from being a trivial concern and has been under focus in even more theoretically oriented research teams up to now (Melchinger et al., 2007).

\section{Individual Mating Plans for SMR in Later Generations}

When combining breeds that differ in synthesis of products such as high MY in HF and high FC in Jersey, inferiority of the F2 generation relative to either backcross should be expected. Superior performance in both directions of synthesis cannot be realized in the F2 (or M2, in the case of 3 breeds, like SMR). The SMR breed was assumed to be a new breed, but based on the ori- 
gins of 3 consolidated breeds, there was a large genetic diversity in it. The focus was especially on suggesting mating plans for prospective later generations of SMR, in which the heterosis effects normally decrease, specifically from $100 \%$ in M1 to $62.5 \%$ in M2. A large genetic distance of mates is likely the main enhancer of heterosis effects expressed at the level of the offspring. Heterosis effects can be managed by utilizing genetic distances between mates as Panicke et al. (1993) suggested. The assumption was that a single offspring will become the more heterozygous at a large number of loci the more divergent the parents are in specific traits. Milk yield and FC are such genetically distant traits in dairy cattle. Breeding values (BV) of prospective dam and sire were suggested to be used for calculating the individual heterosis effect (het) of a targeted trait by means of a simple method, summarized by Wessely (1989):

$$
\text { het }_{\mathrm{ijk}}=\mathrm{b}_{1 \mathrm{k}}\left|\mathrm{D}_{\mathrm{MY}}\right|+\mathrm{b}_{2 \mathrm{k}}\left|\mathrm{D}_{\mathrm{FC}}\right|+\mathrm{b}_{3 \mathrm{k}} \mathrm{D}_{\mathrm{MY}} \mathrm{D}_{\mathrm{FC}},
$$

where $\mathrm{i}=$ a prospective dam; $\mathrm{j}=$ the sire; $\mathrm{k}=$ the targeted trait (e.g., MY, fat yield, protein yield, FC, protein content, and further); and $b_{1 \mathrm{k}} \ldots b_{3 \mathrm{k}}=$ the regression coefficients for the use in calculating auxiliary heterosis effects (e.g., for protein yield) being the targeted trait; $\mathrm{D}_{\mathrm{MY}}$ and $\mathrm{D}_{\mathrm{FC}}$ are so-called divergence measures, which consider $\mathrm{BV}$ of sire $\mathrm{j}$ and dam $\mathrm{i}$ in $\mathrm{MY}$ and $\mathrm{FC}$ :

$$
\begin{aligned}
& \mathrm{D}_{\mathrm{MY}}=\mathrm{W}_{\mathrm{MY}} B V_{\mathrm{i}}-\mathrm{W}_{\mathrm{MYj}} B V_{j} \\
& \mathrm{D}_{\mathrm{FC}}=\mathrm{W}_{\mathrm{FCi}} B V_{\mathrm{i}}-\mathrm{W}_{\mathrm{FCj}} B V_{j},
\end{aligned}
$$

where $\mathrm{W}_{\mathrm{MY}}, \mathrm{W}_{\mathrm{FCi}}, \mathrm{W}_{\mathrm{MY}}$, and $\mathrm{W}_{\mathrm{FCj}}$ describe the assumed linear dependency of calculated daughters performance on the BV of dams (i) and sires (j), obtained from adapting a linear regression function. It represents a simple regression coefficient of $\mathrm{MY}$ and $\mathrm{FC}$ on the targeted trait (e.g., for protein yield). Redmann (1988) calculated and tested such regression coefficients by means of several very large and representative samples based on SMR data. As an example, an additional individual heterosis effect of $+6.4 \mathrm{~kg}$ of protein and $+4.8 \mathrm{~kg}$ of fat was estimated for a BV of a daughter, if the BV of a sire were $+800 \mathrm{~kg}$ of milk and $-0.7 \%$ fat and BV of a dam were $-400 \mathrm{~kg}$ of milk and $+0.4 \%$ fat (Wessely, 1989). In the model described previously, contribution of heterosis is assumed to be high, if the absolute parental BV differences in MY and FC are high. Panicke et al. (1993) suggested involving nonadditive effects in addition to the additive effects for predicting BV of daughters. In comparison to the use of additive effects only, the coefficient of determination increased by $13 \%$ for MY up to 53\% for protein yield, respectively, when the additive and heterosis effects were weighted equally (Wessely, 1989; Panicke et al., 1993). Moreover, in greater production levels, predicted BV of a daughter based on additive and nonadditive effects agreed better to the realized daughter performances than predictions based on additive effects alone. The approach enables a comparison of the predicted outcome for any possible mating in a cow stock for selecting the most promising. It was incorporated in a computer program for individual planning of mating, based on selection index strategy, which was used in research and in a few farms for a short time (Panicke et al., 1993). Again, it should be emphasized that utilizing positive nonadditive effects is just a bonus on top (Sorensen et al., 2008) for improving production and functional traits. The priority of trait-specific additive effects in mating plans and selection has never been doubted.

\section{INCORPORATING SMR INTO GERMAN HOLSTEINS}

Two SMR cows show the heterogeneity of appearance and characteristics (Figures 3 and 4). After the reunification of Germany in 1990, researchers and cattle breeders discussed how to integrate the SMR into the German dairy cattle landscape. Results of scientific studies guided the decisions (Schmidt, 1990), and rapid integration into the German Holstein population was the method selected (Zelfel, 1990a,b, 1991). Several studies of SMR and HF in contemporary cow groups were carried out in Schadtbeck, West Germany (Gravert et al., 1990). Those studies revealed better fertility including calving ease, greater percentage of protein and fat in SMR, and about 7\% lower MY, compared with HF. The same tendency was found in 2 East German studies (Table 7) verifying the SMR superiority in fertility and greater MY in HF. On the basis of the trend during the 1980s, production ability of SMR was expected to be 7,000 to $8,000 \mathrm{~kg}$ of milk in average milking cows, accompanied by much greater percentages in fat and protein than HF (Oschika, 2002). But in practice, SMR cows did not reach the level of MY of West German Holstein cows. Pros and cons of gene preservation and optional methods of integrating SMR into the German Holstein breed were discussed (Wilke, 1991; Mösenthin and Weiher, 1992). The SMR cows were known for their better environmental adaptability and lower sensitivity against stress (Zelfel, 1990a), and the breed could have been of interest for breeding purposes in suboptimal management and feeding conditions or organic farming. In East Germany, limitations in forage and grain supplement disappeared almost overnight. Better environments generally lead to increasing genetic variance as shown by König et al. (2005) for modern large-scale dairy farms in East 


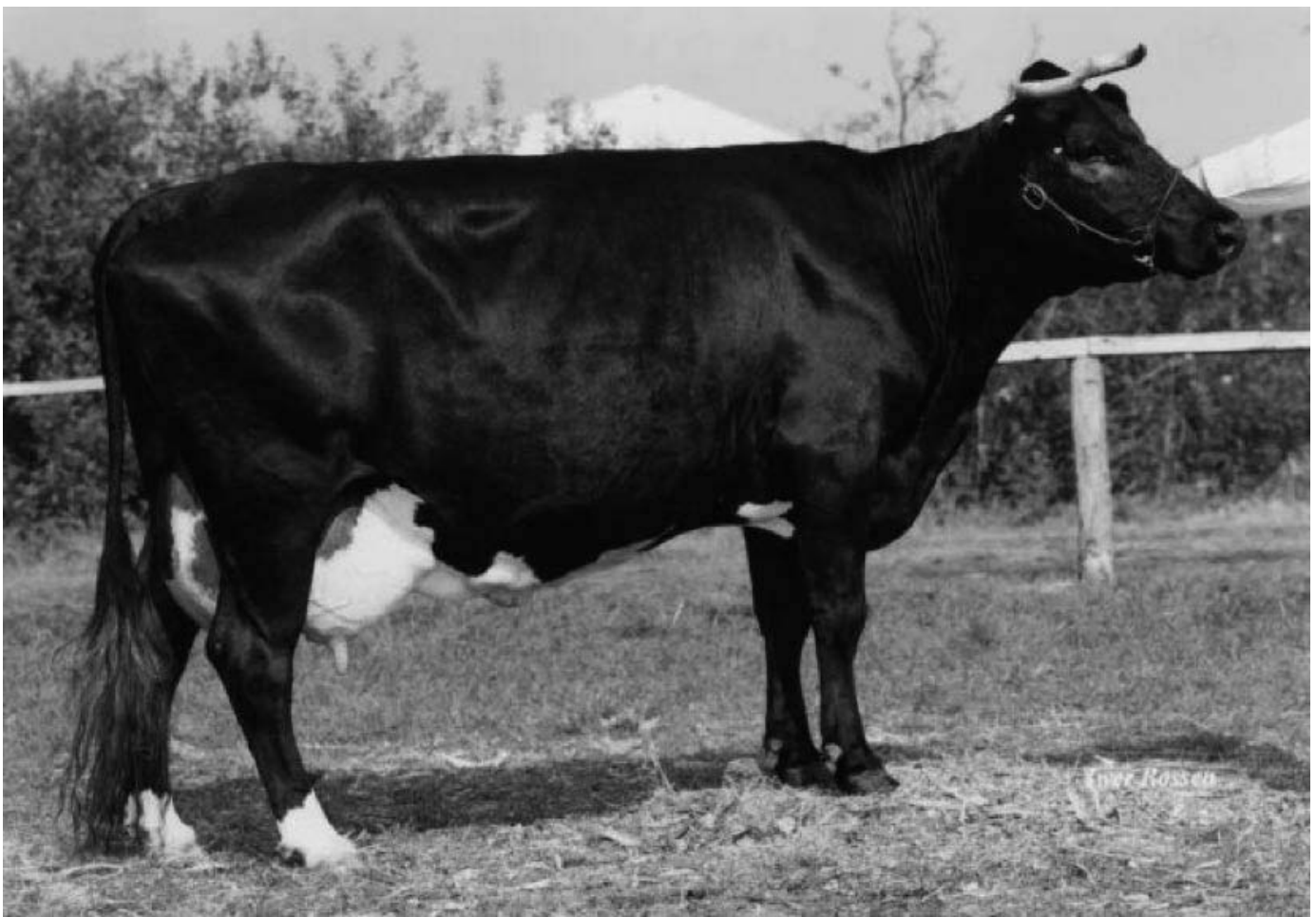

Figure 3. Schwarzbuntes Milchrind der DDR breed cow Orange, male ancestors William $\times$ Profit, lifetime from March 18, 1986 to July 9 , 1998, 10 lactations completed, 3,185 d of use, life performance 75,323 kg of milk, 5.51\% fat (photograph by I. Rossen, Nordhackstedt, 1995).

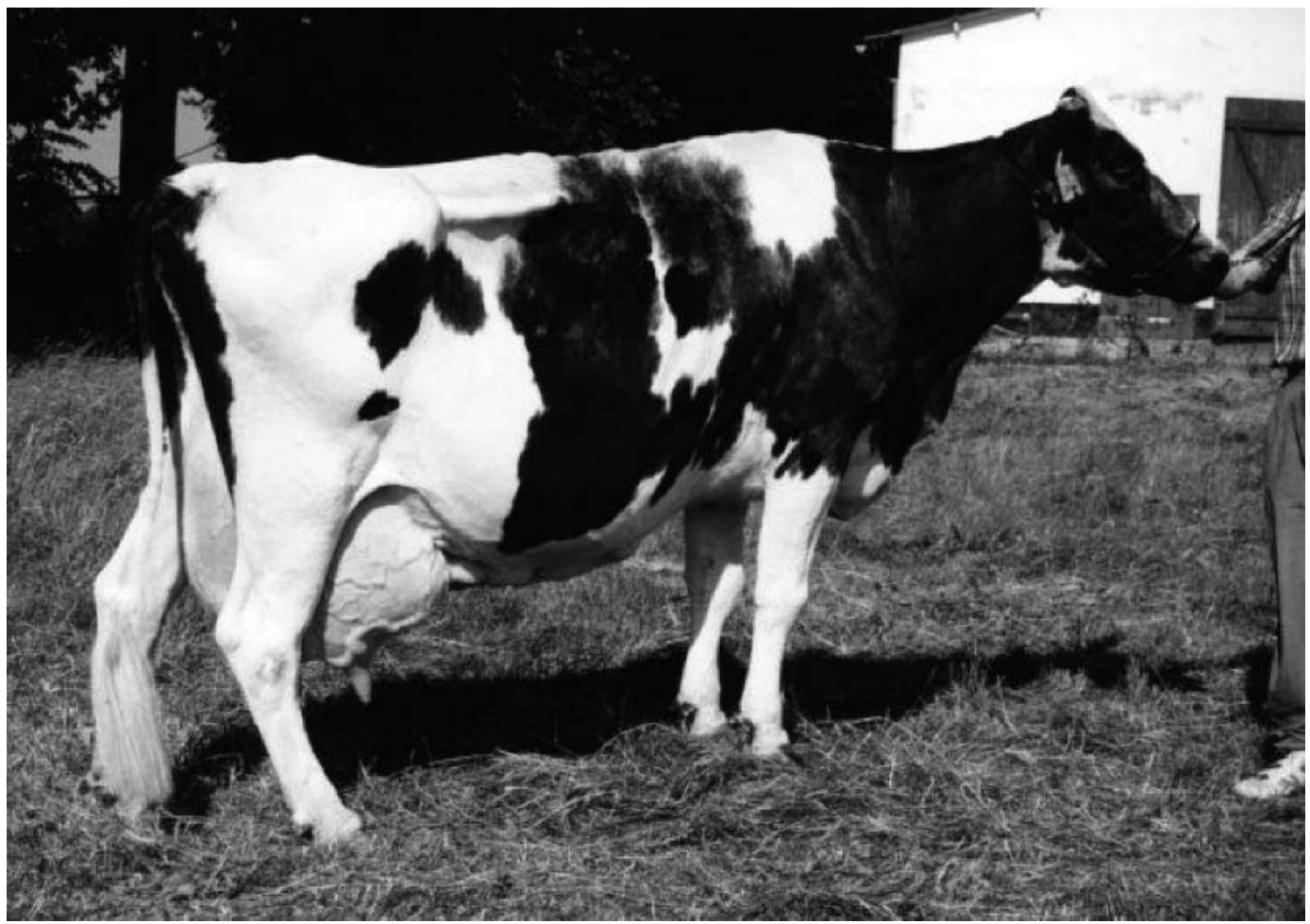

Figure 4. Schwarzbuntes Milchrind der DDR breed cow Waltraud, male ancestors Waterloo $\times$ Wanja, lifetime from May 12,1981 to March 21, 2000, 10 lactations completed, 4,245 d of use, life performance 106,782 kg of milk, 4.73\% fat, 3.42\% protein, 8,702 kg of fat + protein (photograph by R. Schuhmann, Dresden, 1995). 
Table 7. Mean performances in production traits and fertility from different studies: a comparison of breeds at the end of SMR period

\begin{tabular}{|c|c|c|c|c|c|c|c|c|c|}
\hline Breed $^{1}$ & \multicolumn{6}{|c|}{ First lactation performances } & \multicolumn{3}{|c|}{ Functional traits varying among studies } \\
\hline \multicolumn{10}{|l|}{ Schönmuth (1992) } \\
\hline $\mathrm{HF}$ & 77 & 7,358 & 302 & 4.13 & 3.37 & 100 & 78 & 2.8 & 2.7 \\
\hline SMR & 93 & 6,701 & 303 & 4.56 & 3.59 & 115 & 72 & 2.5 & 2.3 \\
\hline & & & & & & & $\begin{array}{l}\text { Service } \\
\text { period }\end{array}$ & $\underset{\text { lactation } 1^{2}}{\operatorname{In}}$ & $\begin{array}{l}\text { Days } \\
\text { open }\end{array}$ \\
\hline $\begin{array}{l}\text { Freyer et al. (1999) } \\
\text { SMR }\end{array}$ & 796 & 5,206 & 226 & 4.37 & 3.51 & 748 & 66.7 & 1.74 & 95.5 \\
\hline $\mathrm{HF}$ & 280 & 5,810 & 244 & 4.23 & 3.37 & 236 & 82.2 & 1.44 & 123.3 \\
\hline SR & 645 & 4,647 & 184 & 3.97 & 3.47 & 424 & 71.8 & 1.60 & 106.7 \\
\hline
\end{tabular}

${ }^{1} \mathrm{BW}=$ Black and White cattle; HF = Holstein-Friesian cattle; SMR = Schwarzbuntes Milchrind der DDR breed; SR = native Black and White cattle population in East Germany.

${ }^{2}$ Average number of services per pregnancy.

Germany. West German breeders complained about black legs in the SMR breed (Gravert et al., 1990). German Holsteins (HOL) have been developed by using $\mathrm{HF}$ sires of North American origin to grade up the native Black and White population in West Germany starting from 1958. Thus, at least 50\% HF genes in the SMR produced a genealogic similarity of the Holstein population in West Germany and SMR. The HF sires were mated in corrective patterns to SMR cows to improve MY and udder traits, whereas SMR sires were used to improve protein and $\mathrm{FC}$ and functional traits. Thus, the SMR population has been incorporated into the German Holstein breed by backcrossing to German Holsteins. It is no longer used in breeding programs as a separate breed.

\section{TIME-RELEVANT CROSSING EXPERIMENTS}

Rotational crosses are necessary if herds are to produce their own replacements without maintaining separate strings of purebred and crossbred cows (Swalve, 2004). If suitable breed combinations can be found, rotational crosses are a good compromise between formation of a new breed and utilization of heterosis. An effective commercial cross will combine desirable additive effects for traits of major economic importance and positive heterosis to improve functionality in commercial settings. But, a commercial cross cannot solve problems of herd management, such as climate control, availability of quality feed, and management conditions essential for good health and fitness. Individual mating plans have to be prepared and consequently respected in rotation crosses (Fischer et al., 2008). Swalve (2007) stated that 2 important questions for long-term crossbreeding with HOL have remained unresolved so far, namely (i) the optimal design, when the dairy herd must produce its own replacements, and (ii) progeny testing individual bull of sire breeds for combining ability with HOL cows.

Several German crossing studies in dairy cattle were carried out before or simultaneously to the SMR breeding period (Averdunk, 1975; Fewson et al., 1975; Kräußlich, 1975; Kögel et al., 1978; Distl et al., 1990). Most of them focused on commercial crossings with beef cattle. In the following, we will concentrate on the motivation of some new ongoing crossing experiments and on their preliminary results. Because much of this work is in progress, only an initial evaluation of findings is possible at this time. The experiments can only be evaluated after a thorough economic analysis that includes all performance indicators and all cows, including calving history and development and fertility in second lactation and all culling reasons of the cows involved in the experiment.

\section{Recent Crossing Experiment with HOL and Jersey}

In Saxony, a large experiment crossing Jersey sires with German Holstein cows is underway, and preliminarily results from $540 \mathrm{~F} 1$ cows are available (Waurich, 2007). The aim of this experiment is mainly to exploit the genetic distance between Jersey and Holstein populations. First results in F1 cows showed improved fertility traits. Brade et al. (2007) and Waurich (2007) reported considerably better results in all fertility parameters, calving ease, and fewer calving losses in F1 cows compared with contemporary pure HOL cows. The F1 cows also displayed greater contents of milk fat and milk protein and lower MY (Table 8). Somatic cell score was lowest in HOL, followed by F1 cows (Wau- 
Table 8. Least squares means and standard error for selected milk traits, general traits, and somatic cell score (SCS), and amount of heterosis of Holstein, Jersey, and F1 crosses in a current trial in Saxony (Waurich, 2007)

\begin{tabular}{|c|c|c|c|c|c|c|c|}
\hline \multirow[b]{2}{*}{ Traits } & \multicolumn{2}{|c|}{ Holstein $\left(\mathrm{n}^{1}=28,065\right)$} & \multicolumn{2}{|c|}{ Jersey $(\mathrm{n}=57)$} & \multicolumn{2}{|c|}{$\mathrm{F} 1(\mathrm{n}=469)$} & \multirow{2}{*}{$\begin{array}{l}\text { Heterosis } \\
(\%)\end{array}$} \\
\hline & Mean & $\mathrm{SE}$ & Mean & $\mathrm{SE}$ & Mean & SE & \\
\hline Milk yield (kg) & 8,435 & 31.6 & 6,151 & 267 & 7,755 & 98 & $6.3^{2}$ \\
\hline Fat content (\%) & 4.12 & 0.011 & 5.80 & 0.092 & 4.75 & 0.034 & -4.2 \\
\hline Protein content (\%) & 3.41 & 0.005 & 4.00 & 0.038 & 3.67 & 0.014 & -0.9 \\
\hline Number of services per pregnancy & 1.80 & 0.014 & 1.70 & 0.100 & 1.67 & 0.041 & $-4.6^{2}$ \\
\hline
\end{tabular}

${ }^{1}$ Number of animals.

${ }^{2}$ Indicates advantageous heterosis effects in F1.

${ }^{3}$ Persistency is the relation of the second $100 \mathrm{~d}$ of milk performance and the first $100 \mathrm{~d}$ of performance within lactation.

rich, 2007). Despite positive heterosis effects, Waurich (2007) did not find absolute superiority of F1 cows over HOL in MY, fat yield, and protein yield, but he found superiority of $\mathrm{F} 1$ cows in $\mathrm{FC}$ and protein content, despite missing heterosis effects. The demand in food energy in megajoules of $\mathrm{NE}_{\mathrm{L}}$ per kilogram of milk protein was somewhat greater in HOL (Brade et al., 2007).

\section{Crossbreeding Experiment with Brown Swiss and $\mathrm{HOL}$}

The goal of a crossbreeding experiment with Brown Swiss (BS) and HOL, called the Iden crossbreeding experiment, is to breed high-yielding and healthy cows that are fertile and easy to manage, without demanding mating plans (Fischer et al., 2008). The experiment is currently being carried out in cooperation with the Martin Luther University Halle (Swalve, 2007). In the HOL herds of Saxony-Anhalt, where the experimental station Iden is located, the average annual milk production increased by $2,400 \mathrm{~kg}$ of milk during the last $10 \mathrm{yr}$, with a simultaneous increase of $26 \mathrm{~d}$ in calving intervals and a decrease in productive life from 3 to $2.4 \mathrm{yr}$. Thus, the crossing experiment was initiated to improve functional traits. Sires of the BS breed were chosen because BS is a milk-emphasized dual-purpose breed in Germany and shows desirable functional characteristics. At least $5 \mathrm{~F} 1$ daughters from each of the $10 \mathrm{BS}$ sires were included in the analysis. Early results from a crossbred group of $\mathrm{BS} \times \mathrm{HOL}$ and $\mathrm{HOL}$ cows are in Table 9. The F1 cows reached almost the same MY as HOL cows, accompanied by significantly greater contents of fat and protein $(P<0.05)$. Further advantages of $\mathrm{F} 1$ cows were related to fertility and health. Stillbirth rate was less than in HOL by about $2 \%$ (results not shown). Calves of commercial crosses were vital, robust, and developed easily. Udder depth and measures of teats of $\mathrm{F} 1$ cows came closer to the demands for machine milking than those of HOL cows. The F1 cows had fewer problems with udder health, and cows treated for mastitis required fewer days of discarded milk than HOL. But, F1 cows showed several disadvantages as well. Their energy intake was significantly greater than in HOL. This implies less

Table 9. Preliminary results from a crossing experiment of Brown Swiss (BS) and German Holstein (HOL) within a milking period of July 2005 to January 2008 comparing F1 cows and HF cows in lactations 1 and $2^{1}$

\begin{tabular}{lcc}
\hline Item & F1 (BS $\times$ HOL) & HOL \\
\hline Number of records & $50 / 46$ & $45 / 40$ \\
Daily milk yield (kg) $^{2}$ Fat content $\left.{ }^{2} \%\right)$ & $30.0 / 39.7$ & $30.6 / 40.7$ \\
Protein content $^{2}(\%)$ & $4.16 / 4.14$ & $3.97 / 3.98$ \\
Days open $_{\text {Mean number of services per conception }}$ & $3.67 / 3.51$ & $3.52 / 3.41$ \\
Lameness - days of treatment & $89.1 / 120.4$ & $106.8 / 128.2$ \\
Height of udder floor (cm) & $1.84 / 1.93$ & $2.00 / 2.23$ \\
Mean milking per minute (kg/min) & $59 / 63$ & $50 / 87$ \\
Days of discarding milk (per cow with udder treatment) & 52.7 & 58.3 \\
\hline
\end{tabular}

${ }^{1} 1 / 2$, reported by Fischer et al. (2008).

${ }^{2}$ Unadjusted. 
Table 10. Population parameters for production and functional traits for German Holstein (HOL), Brown Swiss (BS), and F1 HOL $\times$ BS crosses and prices for delivered milk as used in the modeling of breeding scenarios

\begin{tabular}{|c|c|c|c|c|c|c|c|c|}
\hline \multirow[b]{2}{*}{ Breed } & \multicolumn{4}{|c|}{ Production traits } & \multicolumn{4}{|c|}{ Functional traits } \\
\hline & Milk (kg) & Fat (\%) & Protein (\%) & Price $^{1}(€ / \mathrm{kg})$ & $\begin{array}{l}\text { Productive life } \\
\text { (no. of lactations) }\end{array}$ & $\begin{array}{l}\text { Replacement } \\
\text { rate }(\%)\end{array}$ & $\begin{array}{l}\text { Calving } \\
\text { interval (d) }\end{array}$ & $\begin{array}{l}\text { Calving } \\
\text { rate }(\%)\end{array}$ \\
\hline$\overline{\mathrm{HOL}}$ & 7,894 & 4.14 & 3.37 & 0.3104 & 2.48 & 35.7 & 398 & 91.7 \\
\hline BS & 6,440 & 4.18 & 3.59 & 0.3211 & 3.11 & 25.0 & 411 & 88.8 \\
\hline F1 & 7,525 & 4.16 & 3.48 & 0.3157 & 3.07 & 27.4 & 367 & 99.4 \\
\hline Heterosis (\%) & 5 & 0 & 0 & & 9 & 9 & 9 & 5 \\
\hline
\end{tabular}

${ }^{1}$ Payment system for milk: base price $0.28 € / \mathrm{kg}(3.70 \%$ fat and $3.40 \%$ protein $)+0.0256 €$ per percentage of fat $>3.7 \%$ fat $+0.0409 €$ per percentage of protein $>3.4 \%$ protein $+7 \%$ turnover taxes.

food efficiency given similar yields in fat and protein. The F1 cows showed a better persistency (measured as relation of absolute MY in d 101 to 200 and $d 1$ to 100). More cases of lameness in first lactation were observed in $\mathrm{F} 1$ cows (not tested statistically yet), but no differences were noticed in second lactation.

\section{Crossbreeding Experiment Based on Swedish Red and Holstein}

Swalve (2007) reported an ongoing crossbreeding experiment using Swedish Red bulls and BS bulls on a large organic farm in Brandenburg, where the average milk production per cow and lactation is around $7,500 \mathrm{~kg}$. The crossing groups Swedish Red $\times$ HOL and BS $\times$ HOL comprised 110 and 96 cows, respectively. The breeding strategy is a 3 -way rotational cross. Preliminary results showed that Swedish Red $\times$ HOL cows were distinctly and significantly advantageous over the other breed groups for most of the traits but not for protein content and not for somatic cell score (Swalve,
2007). Survival losses were lowest in Swedish Red $x$ HOL, whereas BS $\times$ HOL was not better than purebred HOL. Both crossbred groups were superior to HOL for the number of services per conception. Results of this experiment thus far suggest that a specific combining ability may not only exist for a specific cross but could be important for individual bulls (Swalve, 2007), corresponding to the suggestion to individual planning of mating (Panicke et al., 1993). The crosses are being studied for their merit as dual-purpose (meat-milk) animals, meaning an additional component for comparison in this study. An example to include heterosis from different breeding designs on economic merit of a breeding system is shown below.

\section{Economic Aspects of Crossbreeding in Germany}

Reports of crossbreeding as summarized in this review have shown evidence of favorable heterosis for several traits. In the following part, the economic gain of a crossbreeding system in 1 region of North-

Table 11. Population parameters for the number of milking cows, lactations, disposals, replacements, and calves for sale for 3 breeding scenarios involving the 3 breeds: German Holstein (HOL), Brown Swiss (BS), and Charolais $(\mathrm{CH})$

\begin{tabular}{lcccc}
\hline & \multicolumn{3}{c}{ Breeding system $^{1}$} \\
\cline { 2 - 4 } Item & $\mathrm{A}$ & $\mathrm{B}$ & $\mathrm{C}$ & Difference (C - B) \\
\hline Cows HOL, $\mathrm{n}$ & 100,000 & 100,000 & 75,472 & \\
Cows F1 (HOL $\times \mathrm{BS}$ ), $\mathrm{n}$ & & & 23,634 & $-0.09 \%$ \\
Total cows, $\mathrm{n}$ & 100,000 & 100,000 & 99,106 & $+1.0 \%$ \\
Lactations, $\mathrm{n}$ & 91,700 & 91,700 & 92,706 & $-4.8 \%$ \\
Disposals, $\mathrm{n}$ & 32,737 & 32,737 & 31,146 & $0.0 \%$ \\
Fat (Mio·kg) & 30.0 & 30.0 & 30.0 & $-4.8 \%$ \\
Replacements/a, n & 32,737 & 32,737 & 31,146 & $-4.8 \%$ \\
Slaughter cows, $\mathrm{n}$ & 32,737 & 32,737 & 31,146 & $+23.9 \%$ \\
Calves for sale, $\mathrm{n}$ & & & & $+23.9 \%$ \\
Male terminal crosses & & 8,528 & 10,572 & $-4.9 \%$ \\
Female terminal crosses & & 8,528 & 10,572 & \\
Male purebred & 41,265 & 32,737 & 31,146 & \\
Female purebred & 8,528 & & & \\
\hline
\end{tabular}

${ }^{1} \mathrm{~A}=$ purebred HOL milking cows and progeny; $\mathrm{B}=$ purebred HOL milking cows and fractions of crossbred calves from $\mathrm{CH}$ bulls for slaughtering; $\mathrm{C}=$ purebred $\mathrm{HOL}$ and crossbred $\mathrm{HOL} \times \mathrm{BS}(\mathrm{F} 1)$ cows for milk production and fractions of calves from $\mathrm{CH}$ bulls $(\mathrm{F} 1 \times \mathrm{CH})$ for slaughtering. 


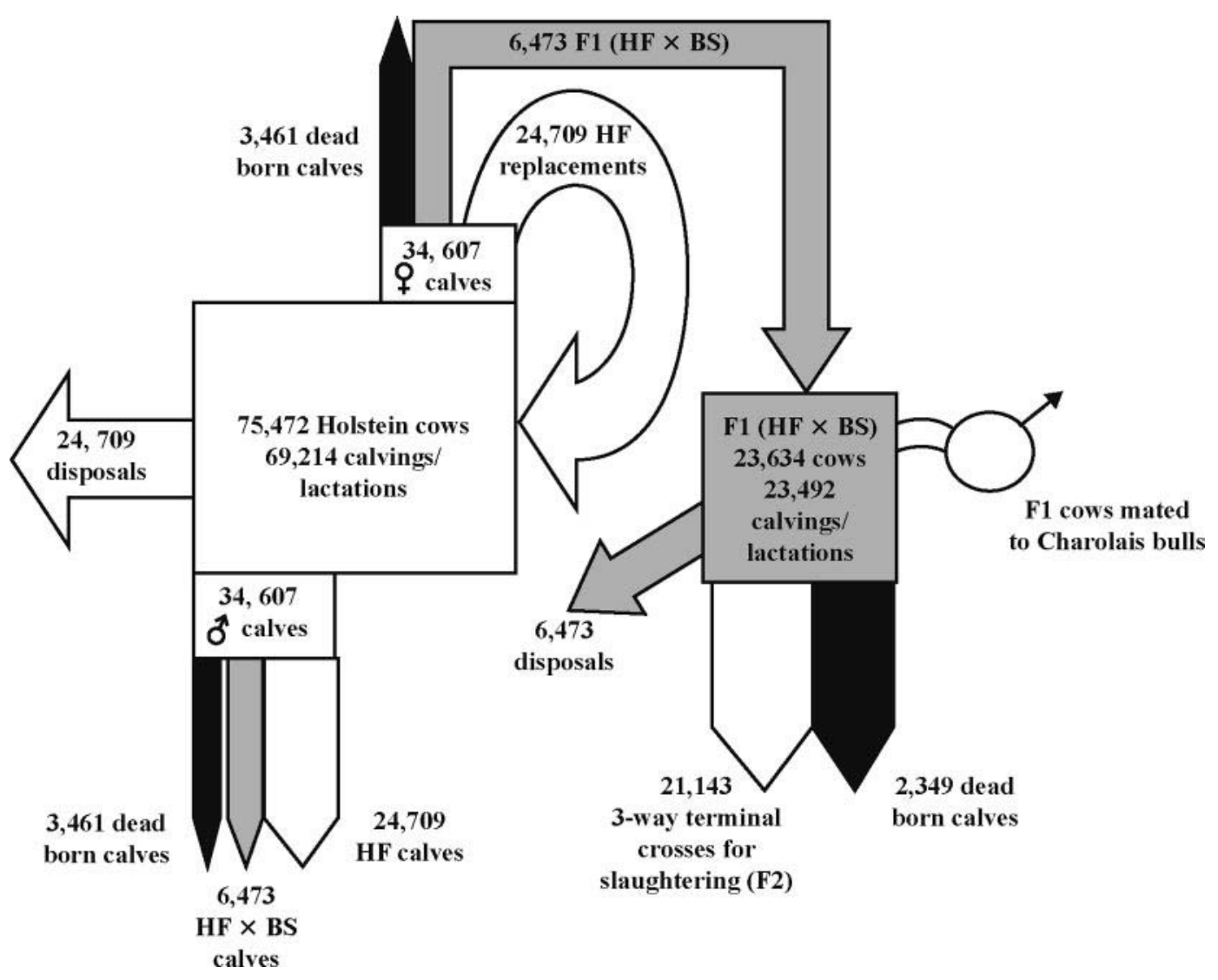

Figure 5. Breeding scenario for a population-wide point of view (100,000 cows) when considering the restrictions of the fulfillment of a fixed fat quota of $30,000 \mathrm{~kg}$ and the replacements for purebred Holstein-Friesian (HF) and crossbred HF $\times$ BS (Brown Swiss) cows.

west Germany will be evaluated and compared with purebred Holsteins utilizing current phenotypic and genetic parameters, as well as current market values for a population of 100,000 cows. An algorithm using a deterministic approach was developed to estimate the potential benefit of crossbreeding (König and Simianer, 2005). A milk quota system for a fixed fat quota of 30 million $\mathrm{kg}$ of fat for different mating systems involving the 3 breeds: HOL, BS, and Charolais $(\mathbf{C H})$ beef cattle was chosen. The scenario for purebred HOL cows served as a base scenario (scenario A). In scenario B, a fraction of the HOL cows were mated to $\mathrm{CH}$ bulls to produce terminal crosses for slaughtering. This required a redistribution of calves for sale to ensure sufficient replacements for purebred milking HOL cows. Scenario $\mathrm{C}$ was a 3 -way discontinuous cross. A first generation of $\mathrm{F} 1$ cows for milk production was generated from matings of BS bulls to purebred HOL cows. Animals (F2) for slaughtering were 3-way crosses with $\mathrm{CH}$ used as a terminal cross sire breed. The restriction in this scenario required replacements for purebred Holstein cows as well as for the F1 cows. Population parameters
(Table 10) were used to model such a symbiotic system (Figure 5; i.e., to ensure the replacements and to fulfill the fixed fat quota). The essential steps in system $\mathrm{C}$ are as follows: a calving rate of $91.7 \%$ implies 34,706 female calves from purebred HOL cows per year. Exactly 24,709 of these calves (purebred HOL) must be used to replace the disposals within the HOL population. Due to $10 \%$ of calves born dead, only 6,473 crossbred female calves (HOL $\times$ BS) are available from matings to BS bulls and are used to replace the disposals within the population of 23,634 milking HOL $\times$ BS cows. The F1 cows are consequently mated to $\mathrm{CH}$ bulls to produce terminal crosses for slaughtering. Hence, the suggested system ensures the utilization of $100 \%$ effects of heterosis as indicated in Table 10 for all crossbred cows, and further losses in following generations due to recombination do not exist. System B considers the same restrictions as described for system $\mathrm{C}$ (i.e., the replacements of HOL cows) and the fulfillment of the fixed fat quota. Population parameters for breeding scenarios A, B, and C are summarized in Table 11. System $\mathrm{C}$ allows a fraction of $25 \%$ milking $\mathrm{HOL} \times \mathrm{BS}$ cows 
when ensuring the replacements for purebred HOL and HOL $\times$ BS as well. Favorable heterosis of $9 \%$ for productive life and replacement rates reduced replacement rates by $4.8 \%$ compared with systems A or B. Favorable heterosis for the calving rate (5\%) in system $\mathrm{C}$ increased the number of marketable crossbred calves for slaughtering by $23.9 \%$.

Profit of system C compared with the purebred system A for different percentages of heterosis for functional traits in the F1 (HOL $\times$ BS cows) was calculated by subtracting aggregated costs from aggregated income. The comparison of all 3 systems assumes the sale of surplus male and female calves for slaughtering. Prices for purebred female HOL and F1 were assumed to be $52 €$ and $117 €$ for male HOL and F1. Prices for female and male crossbred calves from $\mathrm{CH}$ were $93 €$ and $165 €$, respectively. Prices for slaughter cows were $350 €$, and the marginal revenue for $1 \mathrm{~kg}$ of milk was considered to be $0.20 €$. Costs for raising a heifer were $1,150 €$. The economic advantage of system $\mathrm{C}$ varied in the range from 83 to $132 €$ for heterosis effects of 0 and $9 \%$, respectively. The greater profit of crossbreed system $\mathrm{C}$ arises from lower replacement costs and greater prices for slaughter calves from $\mathrm{CH}$ sires. The suggested crossbreed system $\mathrm{C}$ uses the full effects of direct and maternal heterosis in the milking $\mathrm{F} 1$ and the full effects of direct heterosis in the terminal crosses. System C implies genetic uniformity, and no recombination losses within the milking herd compared with other crossbreed alternatives such as rotations.

\section{CONCLUDING REMARKS}

Current studies on crossbreeding in dairy cattle in Germany have a different purpose than the work in East Germany that led to a new breed, SMR. The primary purpose behind the search for new ways to breed dairy cattle is the need to harmonize demands for high milk production with fertility and health (Staufenbiel et al., 2005). Intensive selection for high MY over several decades must consider fitness traits to be successful even longer. Contrary to MY, heritability is low for fertility traits. It is difficult to select on milk production, longevity, and fertility simultaneously. The use of properly constructed selection indices involving traits of interest, by means of a balanced breeding goal, suggests a successful way to improve production and functional traits (Walsh et al., 2007).

Crossbreeding could be an effective way to improve functional traits as many examples have shown, but crossbreeding alone will achieve limited success unless genetic progress for all economically important traits continues within pure breeds utilized in crossbreeding. Depending on the breeding goal, specific traits can be improved by nonadditive genetic effects or by introgression of alleles from a different breed used for grading up the base population, or both. But, the question is whether or not these effects within a cross are large enough. Crossbreeding is suggested to be more sensitive against unexpected risks on the long-term. The production level of SMR and the breeds used to create it were low compared with current dairy cattle populations. This fact and the restricted management conditions could be considered a guarantee that the additive and nonadditive effects on milk traits estimated by the simple dominance model using the HFV data were not biased by large effects causing overestimation. Favorable heterosis effects on secondary traits have been reported of up to 8 or $9 \%$, in both historic and in recent studies. As could be shown by the studies cited, crossbred groups and SMR itself were superior to purebreds in fertility traits and length of productive life. These traits affect economics of milk production considerably, and breeders have to decide individually if there is need to pay special attention to them. Confirming results obtained by a large number of studies based on Holstein-Friesian and Jersey breeds, and other breeds suited as potential crossing partners for German Holstein, do not mean that the research on such crosses has been completed. Genome analysis in combination with advanced statistical genetics will help to reveal the inherent mechanisms of heterosis. A concise and successful use of heterosis effects on production traits in new breeds established by crossbreeding will be possible when these mechanisms are more fully understood.

Heterosis effects in crosses of dairy breeds can be of importance, perhaps especially in lifetime economic comparisons. Breeding organization and managing breeding plans are more demanding when these effects should be exploited systematically, because recombination loss could occur in a consolidated crossbreed, but not in commercial crossings. If farmers used purebred bulls in a rotational system, there is a constant reintroduction of intact haploid genotypes from the various breeds. Experienced breeders in Germany state that they prefer purebred Holstein cattle, given that breeding organization and management are well controlled and detrimental effects of inbreeding are minimized. This attitude is doubtlessly based on the current demand and economic considerations. The genetic antagonism between milk production and functional traits is not that high (Swalve, 2007). Health, fertility, and longevity traits respond well to improved management, even under high production. This relation reflects the magnitude of antagonism. In different (or suboptimal) conditions, targeting crossbreeding would be of greater advantage. 


\section{ACKNOWLEDGMENTS}

We gratefully acknowledge Rinderzuchtverband Mecklenburg-Vorpommern e.G. (Wolldegk) for providing photographs and data. Thanks to Gerhard Dietl (Rostock) for his motivating comments and sharing information on SMR history.

\section{REFERENCES}

ADR. 2007. Rinderproduktion in Deutschland 2006. http://www.adrweb.de Accessed Dec. 11, 2007.

Averdunk, G., A. Gottschalk, H. Kräußlich, and E. Schwarz. 1975. Vorläufige Ergebnisse aus der Kreuzung von Rotbunten Holstein-Friesian mit Fleckvieh in Bayern. BayerischesLandwirtschaftliches-Jahrbuch 6:757-758.

Averdunk, G. 1978. Aktuelle Zuchtfragen und Resultate in der Europäischen Braunviehzucht. Report at the First World Conference of Brown Cattle Breeders, Insbruck, Austria.

Basedow, M. 1998. Die genetische Diversität deutscher Rinderrassen dargestellt durch molekulargenetische Markersysteme. PhD Diss. Universität Kiel, Germany.

Baum, N. 1986. Die Zuchtstrategie zur Weiterentwicklung der Merkmalskombination beim Schwarzbunten Milchrind der DDR. Proc. III Internationales Symposium zur Rinder-zucht, Leipzig, Germany. Band 1:44-55.

Beckert, H.-G., G. Nitzsche, H. J. Schwark, M. Jähne, and K. Fürst. 1986. Nachkommenprü-fung potentieller SMR-Besamungsbullen auf Mast- und Schlachtleistung unter Feld-bedingungen. Proc. III. Internationales Symposium zur Rinderzucht. Leipzig, Germany. Band 1:372-382.

Beckett, R. C., T. M. Ludwick, E. R. Rader, H. Hines, and R. Pearson. 1979. Specific and general combining abilities for production and reproduction among lines of Holstein cattle. J. Dairy Sci. 62:613-620.

Beilig, S. 1987. Bewertung der Körperkapazität von SMR-Kühen. PhD Diss. AdL Berlin, Germany.

Bergfeld, U. 1991. Schätzung von Kreuzungseffekten bei mehreren Ausgangspopulationen. Proc. 9 Leipziger Tierzuchtsymposium Vortrag 13. Leipzig University, Germany.

Borrmann, L., H. J. Schwark, H.-G. Beckert, and K. Fürst. 1986. Schlachtertrag und Schlacht- Zusammensetzung von Mastbullen des Schwarzbunten Milchrindes. Proc. III Internationales Symposium zur Rinderzucht. Leipzig, Germany. Band 2:340346.

Bozo, S., M. Muzsik, A. Dunay, and M. Zolnay. 1983. Erfahrungen bei der Nutzung des SMR - Rindes in einem ungarischen Großbetrieb. Tierzucht 37:284-286.

Brade, E., W. Brade, and M. Klunker. 2007. Kreuzung mit Amerikanischen Jerseys. Milchpraxis 1:17-19.

Breitenstein, K.-G., H. Fiedler, E. Gernand, G. Hanschmann, H. Hartung, H. Lenz, W. Reichardt, and D. Schüler. 1990. Züchtungsexperiment Milcheiweiß“ Zusammen- gefasste Ergebnisse 15jähriger Forschungsarbeit zum Milcheiweiß in der Abteilung Clausberg. Schriftenreihe Genetische Probleme in der Tierzucht, Dummerstorf, Heft 26.

Carlborg, Ö., and C. S. Haley. 2004. Opinion: Epistasis - too often neglected in complex trait studies? Nat. Rev. Genet. 5:618625 .

Dempfle, L. 2004. Perspektiven in der Tierzuchtwissenschaft. Züchtungskunde 76:231-234.

Dickerson, G. E. 1969. Experimental approaches in utilizing breed resources. Anim. Breed. Abstr. 37:191-202.

Dietl, G. 1987. Zur Bewertung von Maternaleffekten beim Rind. PhD Diss. AdL Berlin, Germany.

Distl, O., G. Lechner, and H. Kräußlich. 1990. Analysis of crossbred generations by different genetic models in the German Gelbvieh population. J. Anim. Breed. Genet. 107:196-203.
Droese, N., H. Fiedler, and K.-G. Breitenstein. 1985. Ergebnisse genetischer Untersuchungen zum Milcheiweiß im Prozess der Züchtung des SMR. Arch. Anim. Breed. 33:231-235.

Fewson, D., A. Ott, and H. Schulte-Coerne. 1975. Einkreuzungen von Brown Swiss - Tieren aus den USA in das württembergische Braunvieh. Züchtungskunde 47:382-392.

Fiedler, H., E. Gernand, and E. Instenberg. 1990. Schätzergebnisse genetischer Parameter an selektierten Prüfbullentöchtern des SMR. Arch. Anim. Breed. 29:103-115.

Fischer, B., W. Haacker, H. Blum, T. Bäthge, D. Rodenbeck, L. Helm, E. Riemann, G. Andert, G. Franke, G. Heckenberger, T. Engelhard, S. Blöttner, R. D. Fahr, and H. H. Swalve. 2008. Frisches Blut gewünscht? Ausgewählte Ergebnisse des Kreuzungsversuches Braunvieh $\times$ Deutsche Holstein in Iden. Vortrag zum 26. Tag des Milchviehhalters in Sachsen-Anhalt.

Fleischer, P., M. Metzner, M. Beyerbach, M. Hoedemaker, and W. Klee. 2001. The relationship between milk yield and the incidence of some diseases in dairy cows. J. Dairy Sci. 84:2025-2035.

Freyer, G., Z. Liu, G. Erhardt, and L. Panicke. 1999. Casein polymorphism and relation between milk production traits. J. Anim. Breed. Genet. 116:87-97.

Freyer, G., and L. Panicke. 1993. Heterosisschätzung bei Milchrindkreuzungen. Kolloquium "Adaptation bei Nutztieren und neue Aspekte in der Züchtung." FBN Dummerstorf, 17.18.5.1993, Proc. 1, Vortrag18. FBN Dummerstorf, Germany.

Geissler, B., S. Zelfel, M. Roffeis, G. Grundmann, D. Pfeiffer, G. Brudal, T. Tielke, and A. Fickel. 1989. Aufgaben und Lösungswege zur Weiterentwicklung der Zuchtstrategie beim SMR zur Entwicklung des optimalen Zweinutzungstyps. Forschungs- und Entwicklungsbericht WTZ Tierzucht Paretz., Germany.

Gottensträter, A. 2007. Spiel ohne Grenzen. Wirtschaftlichkeit von Milchviehherden wird nicht nur durch Höchstleistungen bestimmt. Neue Landwirtschaft 8:54-57.

Gravert, H. O., K. Pabst, and H. Schulte Coerne. 1990. Trend Milcheiweiß wird höher bewertet. Tierzucht 44:434-435.

Großhans, T., O. Distl, J. Wolf, and G. Seeland. 1993. Schätzung der Kreuzungseffekte von Milchleistungsmerkmalen bei Anwendung verschiedener genetischer Modelle. Kollquium "Adaptation bei Nutztieren und neue Aspekte in der Züchtung" FBN Dummerstorf, 17.-18.5.1993, Proc. 1 Vortrag 17.

Heringstad, B., R. Rekaya, D. Gianola, G. Klemetsdal, and K. A. Weigel. 2001. Bayesian analysis of liability of clinical mastitis in Norwegian cattle with a threshold model: Effects of data sampling method and model specification. J. Dairy Sci. 84:2337-2346.

Hill, W. G. 1971. Theoretical aspects of crossbreeding. Ann. Genet. Sel. Anim. 3:23-24.

Horn, A. 1973. Die Jersey-Rasse als Kreuzungspartner zur Hebung der Leistungsfähigkeit verschiedener Rinderbestände. Züchtungskunde 45:89-99.

Jacubec, V., J. Wolf, P. Komender, D. Fewson, and Z. Zoukupova. 1987. Crossbreeding in farm animals. J. Anim. Breed. Genet. 104:283-294

Kacser, H., and J. A. Burns. 1981. The molecular basis of dominance. Genetics 97:639-666.

Kögel, S., H. Alps, W. Mittelstädt, and H. Eckhart. 1978. Mastleistung und Schlachtkörper wert von Kreuzungen Brown Swiss $\times$ Braunvieh im Vergleich zu Deutschem Braunvieh. II. Mitteilung:Ergebnisse der Jungbullenmast. Bayer. Landw. Jahrbuch 55:833-842.

König, S., G. Dietl, I. Raeder, and H. H. Swalve. 2005. Genetic relationships for dairy performance between large-scale and small-scale farm conditions. J. Dairy Sci. 88:4087-4096.

König, S., and H. Simianer. 2005. Possibility and profitability of crossbreeding in Holstein dairy cattle. 56th Annual Meeting of EAP in Uppsala, Sweden. Book of Abstracts: 23. Wageningen Acad. Publisher, Wageningen, the Netherlands.

Kramer, G., and R. Wiegand. 1986. Realisierte Merkmalskombination bei SMR Bullenmüt- tern des Rinderstammzuchtzentrums. Proc. III Internationales Symposium zur Rinderzucht Leipzig, Germany. Band 2:317-323. 
Kräußlich, H. 1975. Möglichkeiten der Kreuzungszucht in der Bayerischen Fleckviehpopulation. Bayer. Landw. Jahrbuch $52: 649-654$

Kräußlich, H. 1999. Gibt es Alternativen zur Reinzucht? Züchtungskunde 71:495-506.

Kräußlich, H. 2002. Die Zukunft der Fleckviehzucht. Gedanken über züchterische Strategien. Fleckviehwelt 92:4-9.

Lehmann, G. 1987. Untersuchungen zur Einbeziehung der Nutzungsdauer und Lebensleistung in die Zuchtwertschätzung und Selektion von Milchrindbullen. PhD Diss. AdL Berlin, Germany.

Lenschow, J. 1961. Bericht über Kreuzungsversuche in der Rinderzucht. Z. f. Tierzüchtung und Züchtungsbiologie 75:213214.

Lenschow, J., and K. Tilsch. 1963. Ergebnisse der Kreuzung von Deutschen Schwarzbunten Rindern mit Jerseyrindern. 2:Laktationsleistung und Milchinhaltsstoffe. Arch. Anim. Breed. 6:359-372.

Leuthold, G., and W. Leucht. 1980. Beziehungen zwischen der Wachstumsleistung von Milchrindbullen und ihren korrespondierenden Zuchtwerten für Aufzucht- und Milchleistung. Arch. Anim. Breed. 23:237-248.

Matthes, H.-D., L. Panicke, E.-Ch. Wessely, G. Freyer, and C. Marquardt. 1988. Maternale Effekte in der Milchrindpopulation. Pages 116-123 in Proc. 6 Leipziger Tierzuchtsymposium. Leipzig University, Germany.

Matthes, H.-D., P. Zimmermann, and G. Herrendörfer. 1985. ExperimentelleUntersuchungenzumGrobfutteraufnahmevermögen von SMR-Mastbullen und Ermittlung der Bezie- hungen zwischen verschiedenen Leistungskomplexen beim SMR. Research Report. FZ Dummerstorf, Germany.

Melchinger, A. E., H. F. Utz, H.-P. Piepho, Z.-B. Zeng, and C. C. Schön. 2007. The role of epistasis in the manifestation of heterosis: A systems-oriented approach. Genetics 177:1815-1825.

Mösenthin, J., and O. Weiher. 1992. Gedanken zur Zuchtstrategie beim Schwarzbunten Rind. Rinderzucht MecklenburgVorpommern 1:6-7.

Neumann, W., E. Coym, and O. Weiher. 1980. Die Mast- und Schlachtleistung verschiedener Nachkommengruppen bei Berücksichtigung der genotypischen Leistung und des Wachstumsverlaufes. Arch. Anim. Breed. 23:249-258.

Neumann, W., and W. Zupp. 1986. Zur Leistungsfähigkeit von Nachkommen aus Kreuzungen zwischen Rindern der Zweinutzungs-und Fleischrindrassen. Proc. III Internationales Symposium zur Rinderzucht, Leipzig, Germany. Band 1:383392

Oschika, E. 2002. Aktuelle Aspekte der Rinderzucht - Anforderungen an Zuchtorganisatio nen und Vermarktung. Arch. Anim. Breed. 45:45-50.

Panicke, L. 1986. Weiterentwicklung der Anpaarungs-und Selektionsstrategie für die Stabilisierung der Leistungen beim Schwarzbunten Milchrind der DDR. AdL Berlin Proc. 240:1522 .

Panicke, L., H. Brandhorst, and W. Lehmann. 1990 Heterosisfeldversuch 1975-1989 - Zielstellung, Anlage und Material. AdL Berlin Proc. 290:5-18.

Panicke, L., H. Fiedler, G. Freyer, and J. Biemann. 1982. Indexselektion in der Milchrindzüchtung. Arch. Anim. Breed. 25:109-120.

Panicke, L., and G. Freyer. 1992. Estimation of additive and nonadditive effects in dairy cattle. Arch. Anim. Breed. 35:537-549.

Panicke, L., G. Freyer, N. Künzi, R. Engeler, and H. de Boer. 1993. Computergestützte An- paarungsplanung in der Rinderzucht. Arch. Anim. Breed. 36:277-288

Panicke, L., H.-D. Matthes, E.-Ch. Wessely, G. Freyer, and J. Biemann. 1985. Heterosis in der Milchrindzucht. Tierzucht 39:215-216.

Panicke, L., P. Rybka, and J. Biemann. 1983. Probleme und Ergebnisse der Aufzuchtleistung von SMR-Rindern. Tierzucht $37: 148-149$.
Panicke, L., P. Rybka, S. Engel, E. Schüler, G. Anacker, and K. Lembke. 1975. Studie - Möglichkeit für die planmäßige Nutzung von Heterosis und Inzucht in der Milchrindzüchtung. Research Report, FZ Dummerstorf, Germany.

Pötke, D., and L. Panicke. 1993. Vererbungsleistung von Bullenvätern im Zeitraum der SMR- Züchtung. Rinderzucht MecklenburgVorpommern 2:17-21.

Redmann, R. 1988. Optimierte EDV-gestützte Anpaarungsplanung beim Milchrind. PhD Diss. Universität Rostock, Germany.

Roffeis, M., and S. Zelfel. 1989. Das Schwarzbunte Milchrind (SMR) der DDR-Ein Zwei-nutzungsrind hoher Qualität. Tierzucht 43:355-357.

Rosenberger, E., K.-U. Götz, J. Dodenhoff, K. Krogmeier, R. Emmerling, B. Luntz, and H. Anzenberger. 2004. Überprüfung der Zuchtstrategie beim Fleckvieh. Bericht der Bayerischen Landesanstalt für Landwirtschaft Freising.

Rybka, P. 1979. Die Rinderproduktion der Syrischen Arabischen Republik-BisherigeEn-wicklungundEntwicklungsmöglichkeiten unter besonderer Berücksichtigung der Verbesserung der genetischen Leistungsmöglichkeiten der Rinder. Diss B. Akademie der Landwirtschaftswissenschaften, Berlin, Germany.

Schlie, A. 1949. Wert und Gefahren tierzüchterischer Kreuzungen zum Zwecke der Erzeu- gung von Gebrauchstieren. Züchtungskunde 50:9-19.

Schmidt, J. 1948. Schwarzbunte Niederungskühe und Jerseybullen, Kreuzungsversuche und ihre Auswertung. Züchtungskunde 20:29-39.

Schmidt, D. 1990. Zielgrößen bestimmen und Zukunftsperspektiven gemeinsam entwickeln. Tierzucht 44:386.

Schönmuth, G. 1963. Zur Züchtung eines milchbetonten Zweinutzungsrindes mit hohem Milchfett- und Eiweißgehalt und bestem Euter. Arch. Anim. Breed. 2:79-92.

Schönmuth, G. 1985. Genetische Ressourcen für die Nutztierzüchtung. Wissenschaft und Fortschritt 35:274-276

Schönmuth, G. 1992. SMR der Zukunft. Kuh für suboptimale Bedingungen. Tierzüchter 9:20-23.

Schönmuth, G., and G. Seeland. 1986. Aspekte des Antagonismus beim Zweinutzungsrind, dargestellt am Beispiel des Schwarzbunten Milchrindes (SMR). Proc. III Internationales Symposium zur Rinderzucht. Leipzig, Germany. Band 1:288-295.

Schönmuth, G., A. Wilke, G. Seeland, H. Mitschulitz, and W Sieber. 1980. Ergebnisse der Milchrindzüchtung unter Kreuzungsbedingungen. Arch. Anim. Breed. 23:227-235.

Schüler, L., H. H. Swalve, and K. U. Götz. 2001. Grundlagen der quantitativen Genetik. Ulmer Verlag, Stuttgart, Germany.

Schwalbe, S. 1982. Untersuchungen zur Reproduktionsleistung von Rindern verschiedener genotypischer Gruppen. PhD Diss. AdL Berlin, Germany.

Schwalbe, S. 1986. Züchterische Möglichkeiten zur Verbesserung der Fruchtbarkeitsleistung beim Milchrind. AdL Berlin Proc. 240:41-47.

Schwark, H. J. 1986a. Aspekte der Kombination von Milch- und Fleischleistung in der Rinderzucht. Proc. III Internationales Symposium zur Rinderzucht, Leipzig, Germany. Band 1:20-43.

Schwark, H. J. 1986b. Schlusswort. Proc. III Internationales Proc. Symposium zur Rinderzucht, Leipzig, Germany. Band 2:478482.

Schwerin, M. 2001. Structural and functional genomics in domestic animals: The way to understand the phenotype. J. Appl. Genet. 42:293-308.

Seeland, G. 1986. Leistungsfähige Milchrindpopulationen der Welt. AdL Berlin Proc. 240:23-34.

Seeland, G., G. Schönmuth, and A. Wilke. 1984. Heritabilitätsund genetische Korrelations- koeffizienten von Milchleistungsmerkmalen der Rasse,Schwarzbuntes Milchrind. Tierzucht 38:91-94.

Simianer, H., S. Weigend, and D. Rath. 2006. Strategische Ansätze zur Erhaltung und Nutzung genetischer Diversität innerhalb und zwischen Nutztierpopulationen. Agrarspectrum 39:33-50. 
Sorensen, M. K., E. Norberg, J. Pedersen, and L. G. Christensen. 2008. Crossbreeding in dairy cattle: A Danish perspective. J. Dairy Sci. .doi:10.3168/jds.2008-1273

Stahl, W., O. Liebenberg, K. Schmidt, and G. Koriath. 1959. Studien zur Erblichkeitsschät-zung verschiedener Milcheigenschaften auf der Basis extremer Rassenkreuzung zwischen schwarzbuntem Niederungsvieh und Jersey. Arch. Anim. Breed. 2:351-364.

Staufenbiel, R., U. Reinicke, O. Burkert, J. Weber, H. Behn, S. Mengel, and S. Görner. 2005. Physiologische Grundlagen zur Anwendung des Glukosetoleranztests zur Beurteilung des Stoffwechselreaktionsvermögens von Rindern. Schriftenreihe des FBN Dummerstorf 15:49-64.

Swalve, H.H.. 2004. Kreuzungszucht-auch beim Milchrind eine Alternative? Rind aktuell, Heft 14:25-29.

Swalve, H. H. 2007. Crossbreeding in dairy cattle: International trends and results from crossbreeding data in Germany. Lohmann Inf. 42:38-46.

Walsh, S., F. Buckley, D. P. Berry, M. Rath, K. Pierce, N. Byrne, and P. Dillon. 2007. Effects of breed, feeding system, and parity on udder health and milking characteristics. J. Dairy Sci. 90:57675779 .

Waurich, B. 2007. Einkreuzungseffekte von Jersey-Vatertieren auf die sächsische Holsteinpopulation für Produktions- und Sekundärmerkmale. MS Thesis. Georg-August-Universität Göttingen, Germany.

Wessely, E.-Ch., L. Panicke, and G. Freyer. 1987. Schätzung von Dominanz- und Epistasie- effekten bei der Fettmengenleistung von Milchrindern. Arch. Anim. Breed. 30:485-492.

Wessely, E.-Ch. 1988. Nicht-additive Genwirkung-was ist das? Pages 45-51 in Proc. 6. Tierzuchtsymposium, University of Leipzig, Germany.

Wessely, E.-Ch. 1989. Genetische Kombinationseffekte beim SMR. Genetische Probleme in der Tierzucht . Dummerstorf 21:116121.
Wessely, E.-Ch., G. Freyer, J. Biemann, L. Panicke, E. Vetter, and H.-D. Matthes. 1986. Heterosis in der Milchrindzüchtung. AdL Berlin Proc. 240:35-40.

Wessely, E.-Ch., G. Freyer, and L. Panicke. 1985. Ein Beitrag zu Heterosis und Rekombinati- onsverlust bei der Züchtung des SMR. Pages 107-115 in Proc. 3 Leipziger Tierzuchtsymposium. University of Leipzig, Germany.

Wilke, A. 1991. Zur Milchrindzüchtung - Strategien und Ergebnisse. Tierzucht 45:49-50.

Witt, M., E. Werhahn, and U. E. Pfleiderer. 1973a. Ergebnisse eines langjährigen Kreuzungs-versuches mit dem Schwarzbunt-und dem Jerseyrind. 1. Mitteilung. Zeitschr. Tierzüchtung und Züchtungsbiol. 89:280-290.

Witt, M., E. Werhahn, and U. E. Pfleiderer. 1973b. Ergebnisse eines langjährigen Kreuzungs-versuches mit dem Schwarzbunt-und dem Jerseyrind. 2. Mitteilung. Zeitschr. Tierzüchtung und Züchtungsbiol. 90:16-24.

Wolf, J. 1986. Erfordernisse und züchterische Möglichkeiten zur optimalen Kombination von Milch-und Wachstumsleistung beim Schwarzbunten Milchrind der DDR. Diss B. Akademie der Landwirtschaftswissenschaften, Berlin, Germany.

Zelfel,S.1974.ErgebnissebeiderVerwirklichungdesZuchtprogramms in der Rinderpro-duktion. Tierzucht 28:292-295.

Zelfel, S. 1990a. Wege zur deutschen Einheit in der Schwarzbuntzucht. Tierzucht 44:344-345.

Zelfel, S. 1990b. Die Vorzüge des Schwarzbunten Milchrindes sollten beibehalten werden. Tierzucht 44:386-389.

Zelfel, S. 1991.DieRinderherdbuchzuchtin den neuen Bundesländern. Tierzucht 45:241-243.

Zelfel, S., and W. Sieber. 1986. Beziehungen zwischen Parametern des Wachstums und der Milchleistung bei der Rasse Schwarzbuntes Milchrind der DDR. Proc. III Internationales Symposium zur Rinderzucht. Leipzig, Germany. Band 1:303-309. 